\title{
A Concise Synthesis of ent-Cholesterol
}

\author{
Jitendra D. Belani and Scott D. Rychnovsky* \\ Department of Chemistry, 1102 Natural Sciences II, University of California, Irvine, \\ Irvine, California 92697. \\ Email address: srychnov@uci.edu
}

\section{Supporting Information}

$\underline{\text { Section }}$

Optimization of $\mathrm{CH}$ insertion

Copper mediated conjugate reduction

Hydrogenation conditions to afford trans-hydrindane

General Experimental

Preparation of 4

Preparation of $\mathbf{3}$

Preparation of 6

Preparation of 7

Preparation of $\mathbf{8}$

Preparation of $\mathbf{1 0}$

Preparation of 12

Preparation of $\mathbf{1 7}$

Preparation of ent-Choletersol-19- $\mathrm{d}_{3}$

Details of the X-ray structure for sulfone $\mathbf{1 5}$

Proton and Carbon NMR Spectra of Intermediates
Page

$\mathrm{S} 2$

S3

S6

S7

S7

S9

S9

S10

S11

S11

$\mathrm{S} 13$

S14

S14

S15

S18 


\section{Optimization of the CH Insertion Step:}

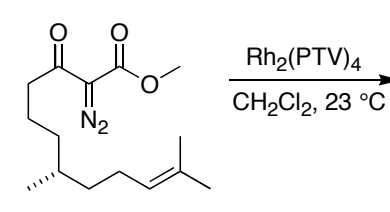

3

Catalyst Structures:

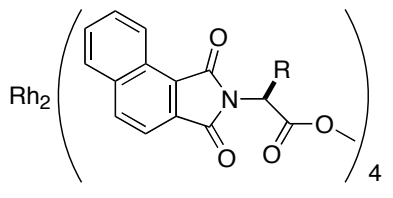

naphthalate series

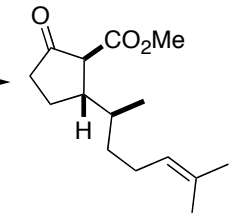

2

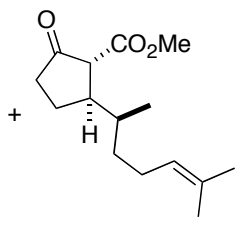

$3.6: 1 \quad 5$

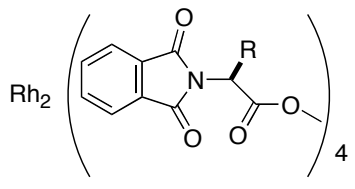

phthalate series

Table 1. Rhodium-catalyzed C-H insertion of diazo keto ester $\mathbf{3}$

$\begin{array}{cccc}\text { entry } & \text { catalyst series } & \text { R-group } & \mathbf{2}: \mathbf{5} \text { ratio }^{\mathrm{a}} \\ 1 & \text { naphthalate } & t \text {-Bu } & 1.74: 1 \\ 2 & \text { naphthalate } & i-\mathrm{Pr} & 1.84: 1 \\ 3 & \text { naphthalate } & \mathrm{Me} & 1.69: 1 \\ 4 & \text { phthalate } & t-\mathrm{Bu} & 2.15: 1 \\ 5 & \text { phthalate } & i-\mathrm{Pr} & 3.60: 1 \\ 6 & \text { phthalate } & \mathrm{Me} & 2.36: 1 \\ 7 & \text { phthalate } & \mathrm{CH}_{2} \mathrm{Ph} & 2.80: 1\end{array}$

${ }^{\mathrm{a}}$ Ratio based on proton NMR integration 


\section{Investigation Into Copper Mediated Conjugate Reduction}

The challenge in the transformation of enone $\mathbf{1}$ to ketone $\mathbf{1 0}$ lies in selective formation of the trans-hydrindane system. There is precedent for a copper mediated conjugate reduction followed by in-situ trapping of the enolate with an electrophile to establish the trans-ring junction with good selectivity. Groth et al. ${ }^{1}$ reported conjugate reduction of a $\mathrm{CD}$ ring synthon in the presence of $\mathrm{CuI}$ using ${ }^{t} \mathrm{BuLi}$-DIBAL mixture followed by alkylation of the aluminum enolate intermediate generated in situ to provide the desired trans-hydrindane system in $71 \%$ yield. Loughlin and Haynes ${ }^{2}$ also reported copper mediated reduction and in-situ trapping of an aluminum enolate with $\mathrm{Br}_{2}$. Daniewski ${ }^{3}$ reported a novel silyl copper catalyst for reductive bromination of the HajosParrish ketone. Desmaele and coworkers, however, have recently reported an interesting and an abnormal preferential formation of a cis-fused thia-hydrindone. ${ }^{4}$

The proposed enone reduction and enolate trapping sequence is shown in Scheme S1. Copper mediated conjugate reduction using DIBAL-H would provide an aluminum enolate and transmetalation to silicon would give a silyl enol ether. In the presence of catalytic $\mathrm{ZnCl}_{2}$, we hoped that alkylation with chloromethyl phenyl sulfide would provide the desired ketone 10. The configuration adjacent to the ketone is unimportant as it will be reestablished in the subsequent reaction, but the selectivity at the ring junction is crucial.

\footnotetext{
${ }^{1}$ Groth, U.; Kohler, T.; Taapken, T. Tetrahedron, 1991, 47, 7583-7592.

${ }^{2}$ Loughlin, W. A.; Haynes, R. K. J Org. Chem. 1995, 60, 807-812.

${ }^{3}$ Daniewski, A. R.; Liu, W. J. Org. Chem. 2001, 66, 626-628.

${ }^{4}$ Danet, M.; Morgant, G.; Tomas, A.; Desmaele, D. Tetrahedron, 2007, 63, 7172-7177.
} 
Scheme S1. Proposed formation of trans-hydrindane system and subsequent alkylation
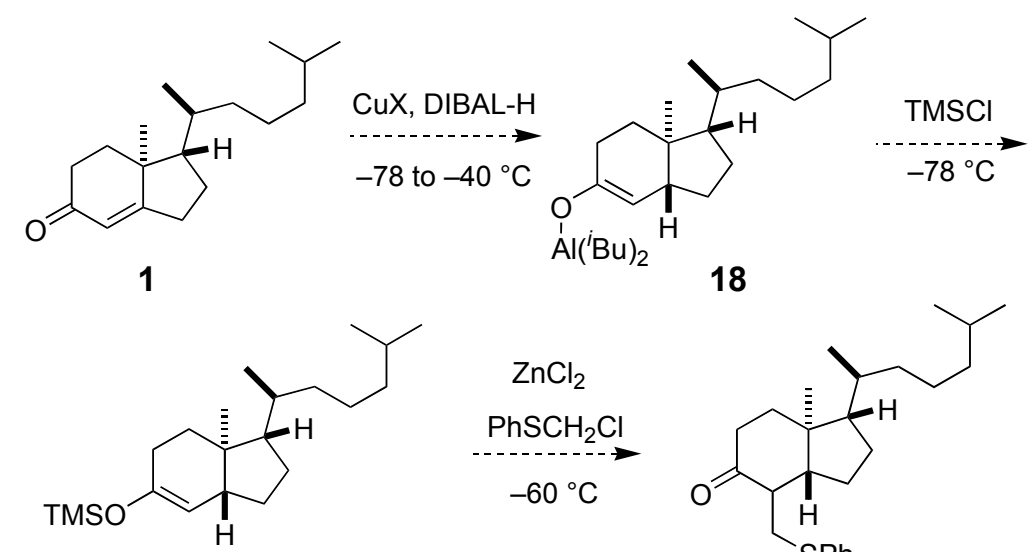

19

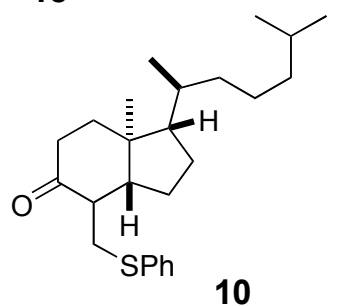

The sequence as shown in Scheme S1 would require an efficient and stereoselective conjugate reduction of enone 1. The conjugate reduction step was investigated, and the results are summarized in Table 2. Copper cyanide and silylcopper were used separately as copper sources. Solvent choice and additives such as HMPA did not influence the selectivity at the ring junction with either copper source. Although yields were generally high, the best selectivity was only 4: 1 in favor of the trans ring junction (entry 6) using silyl copper species in ether. Competing 1,2-reduction was a problem, and the reactions did not always go to completion. The inconsistent results partly reflect the complexity of the reaction. Our inability to separate the minor diastereomer either by column chromatography or crystallization further reduced the attractiveness of the method. Hence, we abandoned further consideration of this approach. 


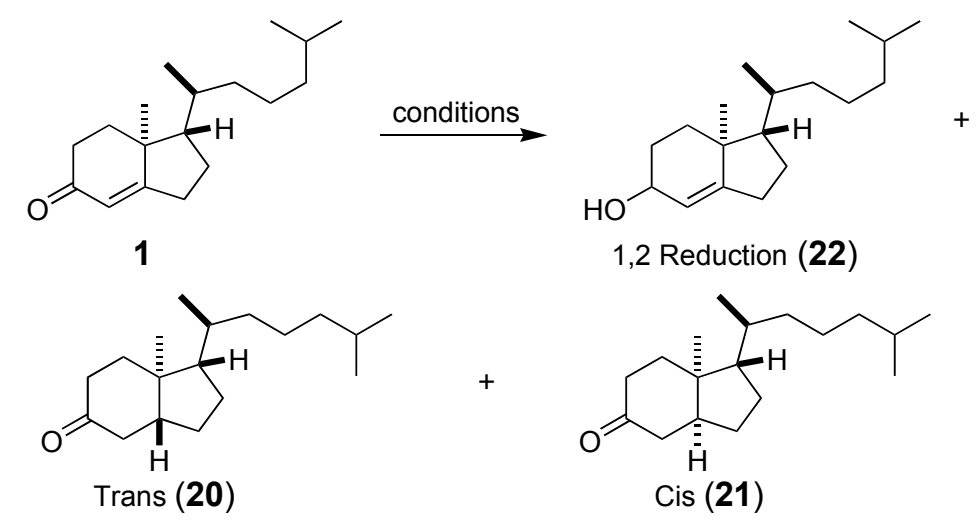

Table 2. Conjugate reduction conditions to afford trans-hydrindane 20.

$\begin{array}{llllll}\text { entry } & \text { conditions }^{\mathrm{a}} & \text { solvent }^{\mathrm{b}} & \text { temp }\left({ }^{\circ} \mathrm{C}\right) & \text { SM:20:21:22 } & \begin{array}{l}\text { trans }^{\text {selectivity }}{ }^{\mathrm{d}} \\ 1\end{array} \\ & \text { A } & \text { THF/HMPA } & -40 & 0: 33: 40: 26 & 45 \% \\ 2 & \text { A } & \text { THF/HMPA } & -78 & 0: 63: 22: 13 & 74 \% \\ 3 & \text { A } & \text { ether/HMPA } & -78 & 16: 27: 43: 14 & 39 \% \\ 4 & \text { A } & \text { THF } & -78 & 0: 24: 51: 24 & 32 \% \\ 5 & \text { B } & \text { THF/HMPA } & -78 & 29: 29: 35: 6 & 45 \% \\ 6 & \text { B } & \text { ether/HMPA } & -78 & 28: 57: 14: 0 & 80 \% \\ 7 & \text { B } & \text { Ether } & -78 & 28: 41: 30: 0 & 58 \%\end{array}$

${ }^{a}$ Conditions A: CuCN, $n \mathrm{BuLi}, \mathrm{HMPA}$, DIBAL System (4 Equiv. of the Cu-Hydride); Conditions B: $\mathrm{PhMe}_{2} \mathrm{Si}-\mathrm{SiMe}{ }_{2} \mathrm{Ph}, \mathrm{MeLi}, \mathrm{CuI}, \mathrm{HMPA}$, DIBAL System (2 Equiv. of the $\mathrm{Cu}$-Hydride) ${ }^{\mathrm{b}} \mathrm{THF} / \mathrm{HMPA}$ ratio $2: 1{ }^{\mathrm{c}}$ The crude yields after filtering through a silica gel plug were ca. $80-90 \%$; ratios were measured by GC. ${ }^{\mathrm{d}}$ Selectivity:20/(20+21)*100 
Scheme S2. Hydrogenation to afford the trans-hydrindane

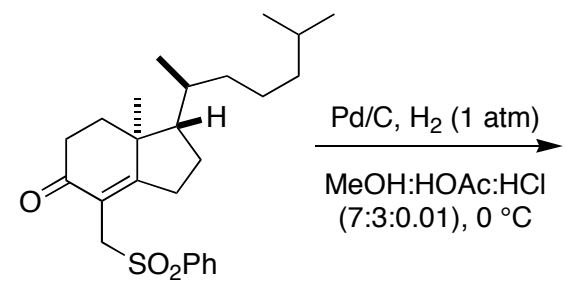

14

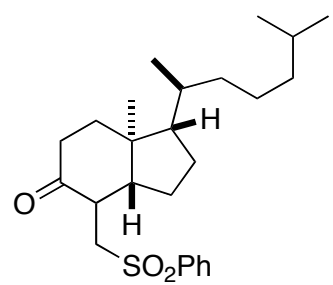

15

$82 \%, 8: 1 \mathrm{dr}$

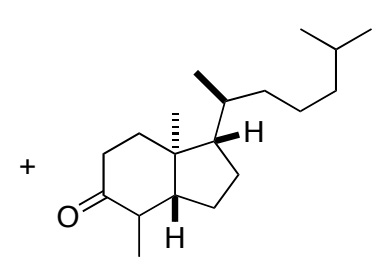

16

$12 \%$

The optimization of the hydrogenation reaction of sulfone $\mathbf{1 4}$ is shown in Table 3 and Scheme S2. The efficiency is high is all cases, but the selectivity improves with increased acidity. The most reproducible results were found using a polar methanolacetic acid mixture with the addition of small amounts of $\mathrm{HCl}$ (entry 8). Elimination of sulfone 15 to the corresponding enone and hydrogenation to $\mathbf{1 6}$ was suppressed by lowering the temperature and by the addition of acid.

Table 3. Hydrogenation of $\mathbf{1 4}$ over $\mathrm{Pd} / \mathrm{C}$ catalyst to produce $\mathbf{1 5}$ (Scheme 6)

\begin{tabular}{|c|c|c|c|c|}
\hline entry & solvent & temp. $\left({ }^{\circ} \mathrm{C}\right)$ & $\mathrm{H}_{2}(\mathrm{psi})$ & 15: trans/cis \\
\hline 1 & $\mathrm{MeOH}$ & 23 & atm. & $4: 1$ \\
\hline 2 & MeOH:HOAc (1:1) & 23 & atm. & $5: 1$ \\
\hline 3 & $\mathrm{MeOH}: \mathrm{HOAc}: \mathrm{HCl}_{(\mathrm{aq})}(7: 2: 1)$ & 23 & 30 & $8: 1$ \\
\hline 4 & TFA: $\mathrm{H}_{2} \mathrm{O}(2: 1)$ & 23 & 30 & $7: 1$ \\
\hline 5 & $\mathrm{HCOOH}$ & 23 & 30 & $7: 1$ \\
\hline 6 & HOAc: $\mathrm{H}_{2} \mathrm{O}(2: 1)$ & 23 & 30 & $9: 1$ \\
\hline 7 & HOAc:HCl(aq) (2:1) & 23 & 50 & $6: 1$ \\
\hline 8 & MeOH:HOAc:HCl $\mathbf{l}_{(\mathrm{aq})}(7: 3: 0.01)$ & $\mathbf{0}$ & atm. & $8: 1$ \\
\hline
\end{tabular}




\section{General Experimental Methods:}

All moisture and air sensitive reactions were carried out in flame-dried glassware using magnetic stirring under positive pressure of argon. Standard syringe/septa techniques were employed. Concentration of organic solutions was accomplished by rotary evaporation. Thin layer chromatography was performed using Whatman silica gel PE SIL G/UV $(0.25 \mathrm{~mm})$ plates. Flash chromatography was performed on Sorbent Technologies 32-63 $\mu \mathrm{M}$ silica gel. Proton NMR spectra were recorded in ppm and were referenced to residual solvent: $\mathrm{CDCl}_{3}(7.26 \mathrm{ppm})$. Data are presented as follows: Chemical shift, multiplicity $(\mathrm{s}=$ singlet, $\mathrm{d}=$ doublet, $\mathrm{t}=$ triplet, $\mathrm{q}=$ quartet $)$, integration and coupling constant(s) in Hertz $(\mathrm{Hz})$. Multiplets $(\mathrm{m})$ are reported over a range $(\mathrm{ppm})$ at which they appear at the indicated field strength. Carbon spectra were recorded in ppm relative to the solvent signal: $\mathrm{CDCl}_{3}(77.3 \mathrm{ppm})$. All commercial reagents were used as received with the exception of the following: DMF was distilled over anhydrous magnesium sulfate, triethylamine was distilled over calcium hydride, methanol was distilled over magnesium turnings and methyl iodide was distilled prior to use.

$\boldsymbol{\beta}$-Ketoester (4). To a solution of $(S)-$ citronellol $\left[\left([\alpha]^{24}{ }_{\mathrm{D}}-3.65, c=1.0, \mathrm{EtOH}\right), 100 \mathrm{~g}\right.$, $0.64 \mathrm{~mol}]$ in $\mathrm{CH}_{2} \mathrm{Cl}_{2}(600 \mathrm{~mL})$, triethylamine $(170 \mathrm{~mL}, 1.28 \mathrm{~mol})$ and DMAP (10 g, 0.08 mol) were added. The solution was cooled to $0{ }^{\circ} \mathrm{C}$ and benzenesulfonyl chloride $(114 \mathrm{~g}$, $0.65 \mathrm{~mol}$ ) was added over a period of $20 \mathrm{~min}$. The reaction mixture was vigorously stirred while a precipitate appeared. After warming the reaction mixture to room temperature and stirring for $4 \mathrm{~h}$, the mixture was filtered and the salts were washed with $\mathrm{Et}_{2} \mathrm{O}(400 \mathrm{~mL})$. The solution was concentrated in vacuo and the crude product residue was passed through a silica plug (400 g) and washed with $500 \mathrm{ml}$ of $20 \%$ EtOAc- 
hexanes. The filtrate was concentrated to afford $190 \mathrm{~g}(99 \%)$ of the product as a yellow oil that was used in the next reaction without purification. Physical and spectroscopic data were consistent with literature data:6 ${ }^{1} \mathrm{H}$ NMR $\left(500 \mathrm{MHz}, \mathrm{CDCl}_{3}\right) \delta 7.86(2 \mathrm{H}, \mathrm{m})$, $7.59(1 \mathrm{H}, \mathrm{m})), 7.50(2 \mathrm{H}, \mathrm{m}), 4.97(1 \mathrm{H}, \mathrm{m}), 4.03(2 \mathrm{H}, \mathrm{m}), 1.87(2 \mathrm{H}, \mathrm{m}), 1.61(4 \mathrm{H}, \mathrm{m})$, $1.51(3 \mathrm{H}, \mathrm{s}), 1.44(1 \mathrm{H}, \mathrm{m}), 1.37(1 \mathrm{H}, \mathrm{m}), 1.21(1 \mathrm{H}, \mathrm{m}), 1.09(1 \mathrm{H}, \mathrm{m}), 0.83(3 \mathrm{H}, \mathrm{d}, J=6.5$ $\mathrm{Hz}) ;{ }^{13} \mathrm{C} \mathrm{NMR}\left(125 \mathrm{MHz}, \mathrm{CDCl}_{3}\right) \delta$ 136.3, 133.7, 131.5, 129.3, 127.9, 124.4 , 76.9, 69.3, 36.7, 35.7, 28.9, 25.7, 25.3, 19.1, 17.7; IR (film in $\mathrm{CDCl}_{3}$ ) 2918, 1451, 1361, 1197, 1077 $\mathrm{cm}^{-1}$.

Dry THF $(500 \mathrm{~mL})$ was transferred to a stirred suspension of $\mathrm{NaH}(17.5 \mathrm{~g}, 60 \%$ dispersion in mineral oil, $0.43 \mathrm{~mol}$, pre-washed with dry hexanes) in a three neck, $3 \mathrm{~L}$ round bottom flask cooled in an ice bath and fitted with an overhead stirrer and an addition flask. Methyl acetoacetate $(50 \mathrm{~g}, 0.43 \mathrm{~mol})$ was added to the suspension slowly over a period of $20 \mathrm{~min}$. Hydrogen gas evolved vigorously during the addition. The clear solution was stirred for $30 \mathrm{~min}$ at $0{ }^{\circ} \mathrm{C}$ and $n$-BuLi (200 mL, $\left.2.16 \mathrm{M}, 0.43 \mathrm{~mol}\right)$ was added through the addition flask over a period of $30 \mathrm{~min}$. The color of the reaction mixture gradually changed to brown-red. After completing the $n$-BuLi addition, the mixture was stirred for additional $30 \mathrm{~min}$ a $0{ }^{\circ} \mathrm{C}$. A solution of the benzene sulfonate derivative of citronellol $(85 \mathrm{~g}, 0.287 \mathrm{~mol})$ in THF ( $450 \mathrm{~mL}$ ) was added to the flask while the mixture was stirred vigorously using an overhead stirrer. A thick precipitate appeared and the reaction mixture was stirred for another $4 \mathrm{~h}$ at room temperature. Saturated $\mathrm{NH}_{4} \mathrm{Cl}(200 \mathrm{~mL})$ and $10 \%$ aq. $\mathrm{HCl}(50 \mathrm{~mL})$ was added to quench the reaction. The organic layer was separated, dried $\left(\mathrm{Na}_{2} \mathrm{SO}_{4}\right)$ and concentrated. The crude yellow oil was loaded on a silica plug $(500 \mathrm{~mL})$ and eluted with $20 \%$ EtOAc-hexanes to afford a pale 
yellow oil that was distilled (bulb-to-bulb, $120-140{ }^{\circ} \mathrm{C}, 0.1 \mathrm{~mm} \mathrm{Hg}$ ) to afford the $\beta$ ketoester 4 (47 g, 65\%) as an oil. Physical and spectroscopic data were consistent with literature data: ${ }^{1} \mathrm{H}$ NMR (500 MHz, $\left.\mathrm{CDCl}_{3}\right) \delta 5.07(1 \mathrm{H}, \mathrm{m}), 3.74(3 \mathrm{H}, \mathrm{s}), 3.45(2 \mathrm{H}, \mathrm{s})$, $2.52(2 \mathrm{H}, \mathrm{t}, J=7.4 \mathrm{~Hz}), 1.96(2 \mathrm{H}, \mathrm{m}), 1.68(3 \mathrm{H}, \mathrm{s}), 1.60(3 \mathrm{H}, \mathrm{s}), 1.6-1.2(6 \mathrm{H}, \mathrm{m}), 1.12$ $(1 \mathrm{H}, \mathrm{m}), 0.87(3 \mathrm{H}, \mathrm{d}, J=6.6 \mathrm{~Hz}) ;{ }^{13} \mathrm{C} \mathrm{NMR}\left(125 \mathrm{MHz}, \mathrm{CDCl}_{3}\right) \delta 202.6,167.5,130.9$, $48.8,43.2,36.8,36.1,25.3,20.8,124.7,52.1,32.1,25.6,19.2,17.5 ;$ IR (film in $\mathrm{CDCl}_{3}$ ) $2918,1451,1361,1197,1077 \mathrm{~cm}^{-1}$.

Diazo- $\beta$-ketoester (3). To a stirred solution of $\beta$-ketoester 4 (60 g, $0.23 \mathrm{~mol})$ in dry acetonitrile $(800 \mathrm{~mL})$ was added triethylamine $(66 \mathrm{~mL}, 0.49 \mathrm{~mol}) . \quad p-$ Acetamidobenzenesulfonylazide $5(74 \mathrm{~g}, 0.30 \mathrm{~mol})$ was added to the reaction mixture, which was then stirred for $20 \mathrm{~h}$ at room temperature. A white precipitate appeared in the reaction mixture that was filtered, and the filtrate was concentrated to afford a crude oil with some dispersed solid. This mixture was loaded on a silica plug $(500 \mathrm{~mL})$ and eluted with $20 \%$ EtOAc-hexanes to afford the diazo compound 3 (64 g, 96\%). Physical and spectroscopic data were consistent with literature data: ${ }^{1} \mathrm{H} \mathrm{NMR}\left(500 \mathrm{MHz}, \mathrm{CDCl}_{3}\right) \delta$ $5.07(1 \mathrm{H}, \mathrm{t}, J=13 \mathrm{~Hz}), 3.81(3 \mathrm{H}, \mathrm{s}), 2.81(2 \mathrm{H}, \mathrm{t}, J=8.1 \mathrm{~Hz}), 1.93(2 \mathrm{H}, \mathrm{m}), 1.66(3 \mathrm{H}, \mathrm{s})$, $1.59(3 \mathrm{H}, \mathrm{s}), 1.45-1.22(6 \mathrm{H}, \mathrm{m}), 1.13(1 \mathrm{H}, \mathrm{m}), 0.85(3 \mathrm{H}, \mathrm{d}, J=6.7 \mathrm{~Hz}) ;{ }^{13} \mathrm{C} \mathrm{NMR}(125$ $\left.\mathrm{MHz}, \mathrm{CDCl}_{3}\right) \delta 193.0,161.9,131.1,125.0,52.2,40.6,36.6,36.5,32.4,29.9,25.8,25.6$, 22.0, 19.5, 17.7; IR (film in $\mathrm{CDCl}_{3}$ ) 2926, 2134, 1727, 1661, $1437 \mathrm{~cm}^{-1}$.

Saturated $\boldsymbol{\beta}$-ketoester (6). A solution of ester 2 (43 g, $0.167 \mathrm{~mol}$ ) was prepared in absolute ethanol $(400 \mathrm{~mL})$ and $5 \% \mathrm{Pd} / \mathrm{C},\left(4 \mathrm{~g}, 50 \% \mathrm{H}_{2} \mathrm{O}\right)$ was added. The flask was

\footnotetext{
${ }^{5}$ Baum, J. S.; Shook, D. A.; Davies, H. M. L.; Smith, H. D. Synth. Commun. 1987, 17, 1709-1716.

${ }^{6}$ Malcolm, S. C.; Taber, D. F. J. Org. Chem. 2001, 66, 944-953.
} 
evacuated three times and subsequently filled with hydrogen. The mixture was stirred under hydrogen at $1 \mathrm{~atm}$. until an aliquot from the reaction showed no olefin proton in the proton NMR spectrum. The mixture was then filtered through Celite and washed with $\mathrm{CH}_{2} \mathrm{Cl}_{2}(200 \mathrm{~mL})$. The filtrate was concentrated to afford $43.2 \mathrm{~g}\left(99 \%, \mathrm{mp}=58^{\circ} \mathrm{C}\right)$ of the desired product as white solid that was taken to the next step without further purification: ${ }^{1} \mathrm{H}$ NMR (400 MHz, $\left.\mathrm{CDCl}_{3}\right) \delta 3.74(3 \mathrm{H}, \mathrm{s}), 2.93(1 \mathrm{H}, \mathrm{d}, J=11.4 \mathrm{~Hz}), 2.54(1 \mathrm{H}, \mathrm{m})$, 2.45-2.25 (2H, m), $2.17(1 \mathrm{H}, \mathrm{m}), 1.50(3 \mathrm{H}, \mathrm{m}), 1.35(2 \mathrm{H}, \mathrm{m}), 1.25-1.00(4 \mathrm{H}, \mathrm{m}), 0.90-$ $0.80(9 \mathrm{H}, \mathrm{m}) ;{ }^{13} \mathrm{C} \mathrm{NMR}\left(100 \mathrm{MHz}, \mathrm{CDCl}_{3}\right) \delta$ 212.5, 170.9, 59.8, 52.6, 47.0, 39.3, 38.9, 37.4, 34.2, 28.1, 25.5, 24.6, 22.9, 22.7, 17.2; IR (film in $\mathrm{CDCl}_{3}$ ) 2965, 1759, 1731, 1435 $\mathrm{cm}^{-1}$; HRMS (ESI) $m / z$ calcd for $\mathrm{C}_{15} \mathrm{H}_{26} \mathrm{O}_{3} \mathrm{Na}(\mathrm{M}+\mathrm{Na})^{+} 277.1779$, found 277.1780.

$\boldsymbol{\beta}$-ketoester (7). To a stirred solution of ester $6(33 \mathrm{~g}, 0.13 \mathrm{~mol})$ in acetone $(400 \mathrm{~mL})$ were added potassium carbonate $(60 \mathrm{~g}, 0.43 \mathrm{~mol})$ and iodomethane $(18 \mathrm{~mL}, 0.3 \mathrm{~mol})$, and the reaction mixture was heated at $50{ }^{\circ} \mathrm{C}$ for $10 \mathrm{~h}$. The mixture was concentrated and the water $(200 \mathrm{~mL})$ was added. The product was extracted using EtOAc $(3 \mathrm{x} 100 \mathrm{~mL})$ to provide $35 \mathrm{~g}$ of crude material. Flash chromatography with 5\% EtOAc-hexanes mixture afforded $31 \mathrm{~g}(88.5 \%)$ of ketone 7 as a colorless oil and $2.9 \mathrm{~g}(8 \%)$ of the $O$-methylated compound. The $O$-methylated compound was dissolved in THF $(50 \mathrm{~mL})$ was treated with $50 \%$ aqueous $\mathrm{HCl}(20 \mathrm{~mL})$ for $2 \mathrm{~h}$. The reaction mixture was treated with solid $\mathrm{NaHCO}_{3}$ and extracted with EtOAc $(50 \mathrm{~mL})$. Concentration followed by flash chromatography of the crude material with $10 \%$ EtOAc-hexanes provided $2.2 \mathrm{~g}(6.6 \%)$ of the starting material 6. The overall yield of the reaction based on recovered starting material was 95\%: $\left([\alpha]^{24}+65.8, c=2.1, \mathrm{EtOH}\right) ;{ }^{1} \mathrm{H}$ NMR $\left(500 \mathrm{MHz}, \mathrm{CDCl}_{3}\right) \delta 3.74(3 \mathrm{H}, \mathrm{s}), 2.93$ $(1 \mathrm{H}, \mathrm{d}, J=11.4 \mathrm{~Hz}), 2.54(1 \mathrm{H}, \mathrm{m}), 2.45-2.25(2 \mathrm{H}, \mathrm{m}), 2.17(1 \mathrm{H}, \mathrm{m}), 1.50(3 \mathrm{H}, \mathrm{m}), 1.35$ 
$(2 \mathrm{H}, \mathrm{m}), 1.25-1.00(5 \mathrm{H}, \mathrm{m}), 0.90-0.80(10 \mathrm{H}, \mathrm{m}) ;{ }^{13} \mathrm{C} \mathrm{NMR}\left(100 \mathrm{MHz}, \mathrm{CDCl}_{3}\right) \delta 212.5$, $170.9,59.8,52.6,47.0,39.3,38.9,37.4,34.2,28.1,25.5,24.6,22.9$ (2C), 22.7, 17.2; IR

(film in $\mathrm{CDCl}_{3}$ ) 2953, 1732, 1755, 1732, $1456 \mathrm{~cm}^{-1}$; HRMS (ESI) $m / z$ calcd for $\mathrm{C}_{16} \mathrm{H}_{28} \mathrm{O}_{3} \mathrm{Na}(\mathrm{M}+\mathrm{Na})^{+}$291.1936, found 291.1938.

D-Ring Ketone (8). Ester 7 (22 g, $0.082 \mathrm{~mol}$ ) was added to a solution of $\mathrm{NaCN}$ (16 g, $0.32 \mathrm{~mol})$ in HMPA $(100 \mathrm{~mL})$, and the reaction mixture was heated at $80{ }^{\circ} \mathrm{C}$ for $3 \mathrm{~h}$. An aqueous solution of $\mathrm{NaOH}(50 \mathrm{~mL}, 2 \mathrm{~N})$ was added to the solution after cooling to room temperature. The mixture was stirred for $30 \mathrm{~min}$ and then extracted with $10 \%$ EtOAchexanes mixture $(500 \mathrm{~mL})$. Concentration followed by column chromatography with 25\% EtOAc-hexanes provided $15.9 \mathrm{~g}(93 \%)$ of the desired ketone $\mathbf{8}$ as a yellow oil : ${ }^{1} \mathrm{H}$ NMR $\left(500 \mathrm{MHz}, \mathrm{CDCl}_{3}\right) \delta 2.33(1 \mathrm{H}, \mathrm{dd}, J=9,19 \mathrm{~Hz}), 2.08(1 \mathrm{H}, \mathrm{m}), 1.96(1 \mathrm{H}, \mathrm{m})$, $1.88(1 \mathrm{H}, \mathrm{m}), 1.63(2 \mathrm{H}, \mathrm{m}), 1.49(2 \mathrm{H}, \mathrm{m}), 1.34(2 \mathrm{H}, \mathrm{m}), 1.15(4 \mathrm{H}, \mathrm{m}), 1.08(3 \mathrm{H}, \mathrm{d}, J$ $=7 \mathrm{~Hz}), 0.958(3 \mathrm{H}, \mathrm{d}, J=7 \mathrm{~Hz}), 0.867(3 \mathrm{H}, \mathrm{d}, J=6.6 \mathrm{~Hz}), 0.854(3 \mathrm{H}, \mathrm{d}, J=6.6 \mathrm{~Hz})$; ${ }^{13} \mathrm{C} \mathrm{NMR}\left(100 \mathrm{MHz}, \mathrm{CDCl}_{3}\right) \delta 222.0,50.3,48.9,39.2,37.4,34.7,32.5,28.0,25.2,23.3$, 22.8, 22.5, 17.8, 13.8; IR (film in $\mathrm{CDCl}_{3}$ ) 2956, 1742, 1469, $1386 \mathrm{~cm}^{-1}$; HRMS (ESI) $m$ / $z$ calcd for $\mathrm{C}_{14} \mathrm{H}_{26} \mathrm{ONa}(\mathrm{M}+\mathrm{Na})^{+} 233.1881$, found 233.1875 .

Thioether (10): Methyl magnesium carbonate, $1.8 \mathrm{~mL}(3.2 \mathrm{mmol}, 3.4$ equiv) of a $1.8 \mathrm{M}$ solution in DMF was added to $0.25 \mathrm{~g}(0.95 \mathrm{mmol}, 1.0$ equiv) of the enone 1 . The solution was heated in an oil bath at $125^{\circ} \mathrm{C}$ for $3 \mathrm{~h}$ while a slow stream of argon was bubbled through the solution. The mixture was cooled and onto a mixture of $50 \mathrm{~mL}$ ice and $3 \mathrm{~mL}$ of concentrated $\mathrm{HCl}$. The aqueous layer was extracted with diethyl ether $(2 \times 50 \mathrm{~mL})$. The organic layer was then washed with aqueous $10 \% \mathrm{NaOH}(2 \times 5 \mathrm{~mL})$. The aqueous 
layer was collected, cooled to $0{ }^{\circ} \mathrm{C}$ and carefully acidified to $\mathrm{pH} 3$ using $3 \mathrm{M} \mathrm{HCl}$ and then extracted with diethyl ether $(3 \times 25 \mathrm{~mL})$. The organic layers were combined, dried over anhydrous $\mathrm{Na}_{2} \mathrm{SO}_{4}$, filtered and concentrated under reduced pressure to give $0.260 \mathrm{~g}$ ( $8.58 \mathrm{mmol}, 90 \%$ yield of crude yellow oil used directly in the next step.

Crude unsaturated acid 9, $0.050 \mathrm{~g}$ ( $0.163 \mathrm{mmol}, 1.0$ equiv) was dissolved in $3 \mathrm{~mL}$ of $\mathrm{MeOH}$ and $0.025 \mathrm{~g}$ of $5 \% \mathrm{Pd} / \mathrm{BaSO}_{4}$ was added to the flask. The flask was evacuated and then filled with argon twice, then evacuated again and filled with hydrogen. The mixture was stirred at $10^{\circ} \mathrm{C}$ for $2 \mathrm{~h}$. The reaction was monitored by mass spectrum. After the reaction was complete, the mixture was filtered through Celite and then concentrated under low temperature $\left(-5^{\circ} \mathrm{C}\right)$ to yield $0.049 \mathrm{~g}$ of very viscous oil that was treated with a premixed, and chilled $\left(0{ }^{\circ} \mathrm{C}\right)$ solution of DMSO $(5 \mathrm{~mL})$, aqueous formaldehyde $(3 \mathrm{~mL})$, and piperidine $(0.2 \mathrm{~mL})$. After stirring the reaction mixture for $10 \mathrm{~min}$ at room temperature, methylene chloride $(10 \mathrm{~mL})$, thiophenol $(0.5 \mathrm{~mL})$, and triethylamine $(1 \mathrm{~mL})$ were added and reaction mixture was stirred for $30 \mathrm{~min}$ at room temperature. The reaction mixture was washed with $10 \% \mathrm{NaOH}$, concentrated and chromatographed with 5-10\% EtOAc-hexanes to provide $0.036 \mathrm{~g}$ (57\% over two steps) of the thioether $\mathbf{1 0}$ as a yellow oil. Thioether 10: $\left([\alpha]^{24} \mathrm{D}-19.6, c=0.9, \mathrm{CHCl}_{3}\right) ;{ }^{1} \mathrm{H} \mathrm{NMR}\left(500 \mathrm{MHz}, \mathrm{CDCl}_{3}\right) \delta$ $7.33(2 \mathrm{H}, \mathrm{m}), 7.27(2 \mathrm{H}, \mathrm{m}), 7.16(1 \mathrm{H}, \mathrm{m}), 3.22(1 \mathrm{H}, \mathrm{dd}, J=6.6,12.9 \mathrm{~Hz}), 2.98(1 \mathrm{H}$, d, $J=3.6,12.7 \mathrm{~Hz}), 2.63(1 \mathrm{H}, \mathrm{m}), 2.49(1 \mathrm{H}, \mathrm{m}), 2.36(1 \mathrm{H}, \mathrm{m}), 2.16(1 \mathrm{H}, \mathrm{m}), 1.96(1 \mathrm{H}$, m), 1.81-1.66 (2 H, m), 1.62-1.50 (2 H, m), 1.48-1.30 (5 H, m), 1.26-1.10 (4 H, m), 1.06$1.0(1 \mathrm{H}, \mathrm{m}), 0.98(3 \mathrm{H}, \mathrm{s}), 0.94(3 \mathrm{H}, \mathrm{d}, J=6.6 \mathrm{~Hz}), 0.86(6 \mathrm{H}, \mathrm{m}) ;{ }^{13} \mathrm{C} \mathrm{NMR}(100 \mathrm{MHz}$, $\left.\mathrm{CDCl}_{3}\right) \delta 210.9,137.9,129.0(3 \mathrm{C}), 125.8(2 \mathrm{C}), 55.1,51.5,43.1,39.6,38.4,37.9,36.0$, 
35.7, 31.6, 29.2, 28.1, 25.2, 23.9, 22.9, 22.7, 18.7, 11.6; HRMS (ESI) $m / z$ calcd for $\mathrm{C}_{25} \mathrm{H}_{38} \mathrm{OSNa}(\mathrm{M}+\mathrm{Na})^{+}$409.2541, found 409.2532.

Tricyclic Enone (12) from Thioether (10). To a solution of freshly prepared NaOMe (9 mg, $0.39 \mathrm{mmol}, 3.0$ equiv.), $\beta$-keto ester 11 (30 mg, $0.12 \mathrm{mmol}, 1.25$ equiv.) was added as a solution in $\mathrm{MeOH}(1 \mathrm{~mL})$ at $10{ }^{\circ} \mathrm{C}$ and the mixture was stirred for $15 \mathrm{~min}$. A solution of thioether $\mathbf{1 0}$ (36 mg, $0.093 \mathrm{mmol}, 1$ equiv.) in dry benzene (1 mL) was added and the reaction mixture was stirred at room temperature for $10 \mathrm{~h}$. A solution of $\mathrm{NaOH}$ $(0.25 \mathrm{~g})$ in $\mathrm{H}_{2} \mathrm{O}(1 \mathrm{~mL})$ was added to the reaction mixture. Sufficient $\mathrm{MeOH}(\sim 25 \mathrm{~mL})$ was added to cause formation of one layer. The mixture was stirred for $2 \mathrm{~h}$ at $23{ }^{\circ} \mathrm{C}$ and then concentrated. Toluene $(10 \mathrm{~mL})$ and $\mathrm{H}_{2} \mathrm{O}(10 \mathrm{~mL})$ were added and the mixture was cooled to $0{ }^{\circ} \mathrm{C}$. An aqueous solution of HOAc (50\%) was added drop wise till the $\mathrm{pH}$ was $\sim 4$. Mixture was extracted with toluene $(2 \times 10 \mathrm{~mL})$, the organic layers were mixed and dried $\left(\mathrm{Na}_{2} \mathrm{SO}_{4}\right)$, and concentrated to provide a yellow oil. The oil was heated at $80{ }^{\circ} \mathrm{C}$ for $3 \mathrm{~h}$ under vacuum (0.2 Torr). The crude material was then chromatographed on silica gel with $10 \%$ EtOAc-hexanes to provide $31 \mathrm{mg}(73 \%)$ of desired tricyclic enone 12. Physical and spectroscopic data were consistent with literature data: $\left([\alpha]^{24}+18.4, c=1.2, \mathrm{CHCl}_{3}\right)$; ${ }^{1} \mathrm{H}$ NMR $\left(500 \mathrm{MHz}, \mathrm{CDCl}_{3}\right) \delta 3.93(4 \mathrm{H}, \mathrm{m}), 2.76(1 \mathrm{H}, \mathrm{m}), 2.46(2 \mathrm{H}, \mathrm{m}), 2.36(1 \mathrm{H}, \mathrm{td}$, $J=5.2,11.9 \mathrm{~Hz}), 2.25(3 \mathrm{H}, \mathrm{m}), 2.12(1 \mathrm{H}, \mathrm{m}), 1.98(1 \mathrm{H}, \mathrm{m}), 1.90(1 \mathrm{H}, \mathrm{m}), 1.70-1.45$ (5 H, m), $1.42(2 \mathrm{H}, \mathrm{m}), 1.36(3 \mathrm{H}, \mathrm{s}), 1.34-1.27$ (3 H, m), 1.20-1.08 (6 H, m), $1.00(1 \mathrm{H}$, m), $0.93(3 \mathrm{H}, \mathrm{d}, J=6.5 \mathrm{~Hz}), 0.871(3 \mathrm{H}, \mathrm{d}, J=6.6 \mathrm{~Hz}), 0.865(3 \mathrm{H}, \mathrm{d}, J=6.6 \mathrm{~Hz}), 0.82$ (3 H, s); ${ }^{13} \mathrm{C}$ NMR (125 MHz, $\left.\mathrm{CDCl}_{3}\right) \delta 198.8,159.9,133.6,110.0,64.8$ (2C), 56.5, 42.1, $39.6,39.4,39.1,38.3,37.3,36.2,35.8,28.4,28.1,27.3,27.1,24.6,23.9,23.7,22.9$ (2C), 
22.7, 20.1, 18.7, 11.4; IR (film in $\mathrm{CDCl}_{3}$ ) 2952, 1667, 1466, 1373, $1060 \mathrm{~cm}^{-1}$; HRMS (ESI) $m / z$ calcd for $\mathrm{C}_{28} \mathrm{H}_{46} \mathrm{O}_{3} \mathrm{Na}(\mathrm{M}+\mathrm{Na})^{+} 453.3347$, found 453.3345 .

Tricyclic Ketone- $\boldsymbol{d}_{3}$ (17). The same procedure reported for tricyclic ketone 13 was followed except that $\mathrm{CD}_{3} \mathrm{I}$ was substituted for $\mathrm{CH}_{3} \mathrm{I}$. Ketone 17: ${ }^{1} \mathrm{H}$ NMR $(500 \mathrm{MHz}$, $\left.\mathrm{CDCl}_{3}\right) \delta 3.93(4 \mathrm{H}, \mathrm{m}), 2.51(1 \mathrm{H}, \mathrm{td}, J=6.4,14.6 \mathrm{~Hz}), 2.24(1 \mathrm{H}, \mathrm{m}), 2.02(1 \mathrm{H}, \mathrm{m})$, 1.95-1.80 (4 H, m), 1.72-1.30 (8 H, m), $1.35(3 \mathrm{H}, \mathrm{s}), 1.32-1.21$ ( $6 \mathrm{H}, \mathrm{m}), 1.20-1.10(6 \mathrm{H}$, m), 1.05-0.95 (1 H, m), $0.89(3 \mathrm{H}, \mathrm{d}, J=6.5 \mathrm{~Hz}), 0.84(3 \mathrm{H}, \mathrm{d}, J=6.6 \mathrm{~Hz}), 0.82(3 \mathrm{H}, \mathrm{d}$, $J=6.6 \mathrm{~Hz}), 0.69(3 \mathrm{H}, \mathrm{s})$, [note: singlet for $\mathrm{C} 19$ at 1.08 is absent when compared to compound 13]; ${ }^{13} \mathrm{C}$ NMR $\left(125 \mathrm{MHz}, \mathrm{CDCl}_{3}\right) \delta$ 215.5, 110.4, 64.6, 64.5, 56.2, 56.0, 50.4, $47.4,42.7,39.6,38.4,36.3,35.9,35.0,33.2,31.4,29.2,28.29,28.20,24.4,23.6,23.0$, $22.75,21.4,18.7,12.1$ [Note: peak at $21.2 \mathrm{ppm}$ is absent when compared to compound 13]; IR (film in $\mathrm{CDCl}_{3}$ ) 2936, 1707, 1467, $1368 \mathrm{~cm}^{-1} . \delta{ }^{2} \mathrm{H}$ NMR $\left(500 \mathrm{MHz}, \mathrm{CDCl}_{3}\right) \delta$ $1.03(3 \mathrm{H}, \mathrm{bs})$.

ent-Cholesterol-19d $d_{3}$ : The same procedure was followed as reported for the synthesis of ent-cholesterol: ${ }^{1} \mathrm{H}$ NMR (500 MHz, $\left.\mathrm{CDCl}_{3}\right) \delta 5.34(1 \mathrm{H}, \mathrm{m}), 3.51(1 \mathrm{H}, \mathrm{t}, J=6.1 \mathrm{~Hz})$, $2.27(2 \mathrm{H}, \mathrm{m}), 2.01(2 \mathrm{H}, \mathrm{m}), 1.86-1.77(3 \mathrm{H}, \mathrm{m}), 1.60-1.39(8 \mathrm{H}, \mathrm{m}), 1.39-1.19(6 \mathrm{H}, \mathrm{m})$, 1.18-1.02 (8 H, m), $0.92(3 \mathrm{H}, \mathrm{d}, J=6.6 \mathrm{~Hz}), 0.867(3 \mathrm{H}, \mathrm{d}, J=6.6 \mathrm{~Hz}), 0.854(3 \mathrm{H}, \mathrm{d}, J$ $=6.6 \mathrm{~Hz}), 0.67(3 \mathrm{H}, \mathrm{s})$, [Note: Singlet for C19 methyl at 1.03 is absent when compared to ent-cholesterol]; ${ }^{13} \mathrm{C}$ NMR (125 MHz, $\left.\mathrm{CDCl}_{3}\right) \delta 140.9,121.8,71.9,56.9,56.3,50.3$, $42.5,40.0,39.7,37.4,36.5,36.4,36.0,32.1,31.8,29.7,28.4,28.2$ (2C), 24.5, 24.0, 23.0, 22.7, 21.3, 18.9, 12.0, [Note: the peak at $19.6 \mathrm{ppm}$ is absent for $\mathrm{C} 19$ carbon when compared to ent-cholesterol]; ${ }^{2} \mathrm{H} \mathrm{NMR}\left(500 \mathrm{MHz}, \mathrm{CDCl}_{3}\right) \delta 0.988(3 \mathrm{H}, \mathrm{bs})$. 
X-ray Data Collection, Structure Solution and Refinement for sulfone 15.

A colorless crystal of approximate dimensions $0.08 \times 0.37 \times 0.38 \mathrm{~mm}$ was mounted on a glass fiber and transferred to a Bruker CCD platform diffractometer. The SMART ${ }^{1}$ program package was used to determine the unit-cell parameters and for data collection $(25 \mathrm{sec} /$ frame scan time for a sphere of diffraction data). The raw frame data was processed using SAINT $^{2}$ and SADABS ${ }^{3}$ to yield the reflection data file. Subsequent calculations were carried out using the SHELXTL ${ }^{4}$ program. The diffraction symmetry was $2 / m$ and the systematic absences were consistent with the monoclinic space groups $P 2_{1}$ and $P 2_{1} / m$. It was later determined that the noncentrosymmetric space group $P 2_{1}$ was correct.

The structure was solved by direct methods and refined on $\mathrm{F}^{2}$ by full-matrix least-squares techniques. The analytical scattering factors ${ }^{5}$ for neutral atoms were used throughout the analysis. Hydrogen atoms were located from a difference-Fourier map and refined (x,y,z and $\mathrm{U}_{\text {iso }}$ ). At convergence, $w \mathrm{R} 2=0.0772$ and $\mathrm{Goof}=1.037$ for 414 variables refined against 5733 data $(0.75 \AA)$. As a comparison for refinement on $\mathrm{F}, \mathrm{R} 1=0.0299$ for those 5357 data with $\mathrm{I}>2.0 \sigma(\mathrm{I})$. The absolute structure was assigned by refinement of the Flack parameter ${ }^{6}$. 
References.

1. SMART Software Users Guide, Version 5.1, Bruker Analytical X-Ray Systems, Inc.; Madison,WI 1999.

2. SAINT Software Users Guide, Version 6.0, Bruker Analytical X-Ray Systems, Inc.; Madison, WI 1999.

3. Sheldrick, G. M. SADABS, Version 2.10, Bruker Analytical X-Ray Systems, Inc.; Madison, WI 2002.

4. Sheldrick, G. M. SHELXTL Version 6.12, Bruker Analytical X-Ray Systems, Inc.; Madison, WI 2001.

5. International Tables for X-Ray Crystallography 1992, Vol. C., Dordrecht: Kluwer Academic Publishers.

6. Flack, H. D. Acta. Cryst., A39, 876-881, 1983.

Definitions:

$\mathrm{wR} 2=\left[\Sigma\left[\mathrm{w}\left(\mathrm{F}_{\mathrm{o}}^{2}-\mathrm{F}_{\mathrm{c}}{ }^{2}\right)^{2}\right] / \Sigma\left[\mathrm{w}\left(\mathrm{F}_{\mathrm{o}}^{2}\right)^{2}\right]\right]^{1 / 2}$

$\mathrm{R} 1=\Sigma|| \mathrm{F}_{\mathrm{o}}|-| \mathrm{F}_{\mathrm{c}}|| / \Sigma\left|\mathrm{F}_{\mathrm{o}}\right|$

Goof $=\mathrm{S}=\left[\Sigma\left[\mathrm{w}\left(\mathrm{F}_{\mathrm{o}}{ }^{2}-\mathrm{F}_{\mathrm{c}}{ }^{2}\right)^{2}\right] /(\mathrm{n}-\mathrm{p})\right]^{1 / 2}$ where $\mathrm{n}$ is the number of reflections and $\mathrm{p}$ is the total number of parameters refined.

The thermal ellipsoid plot is shown at the 50\% probability level. 


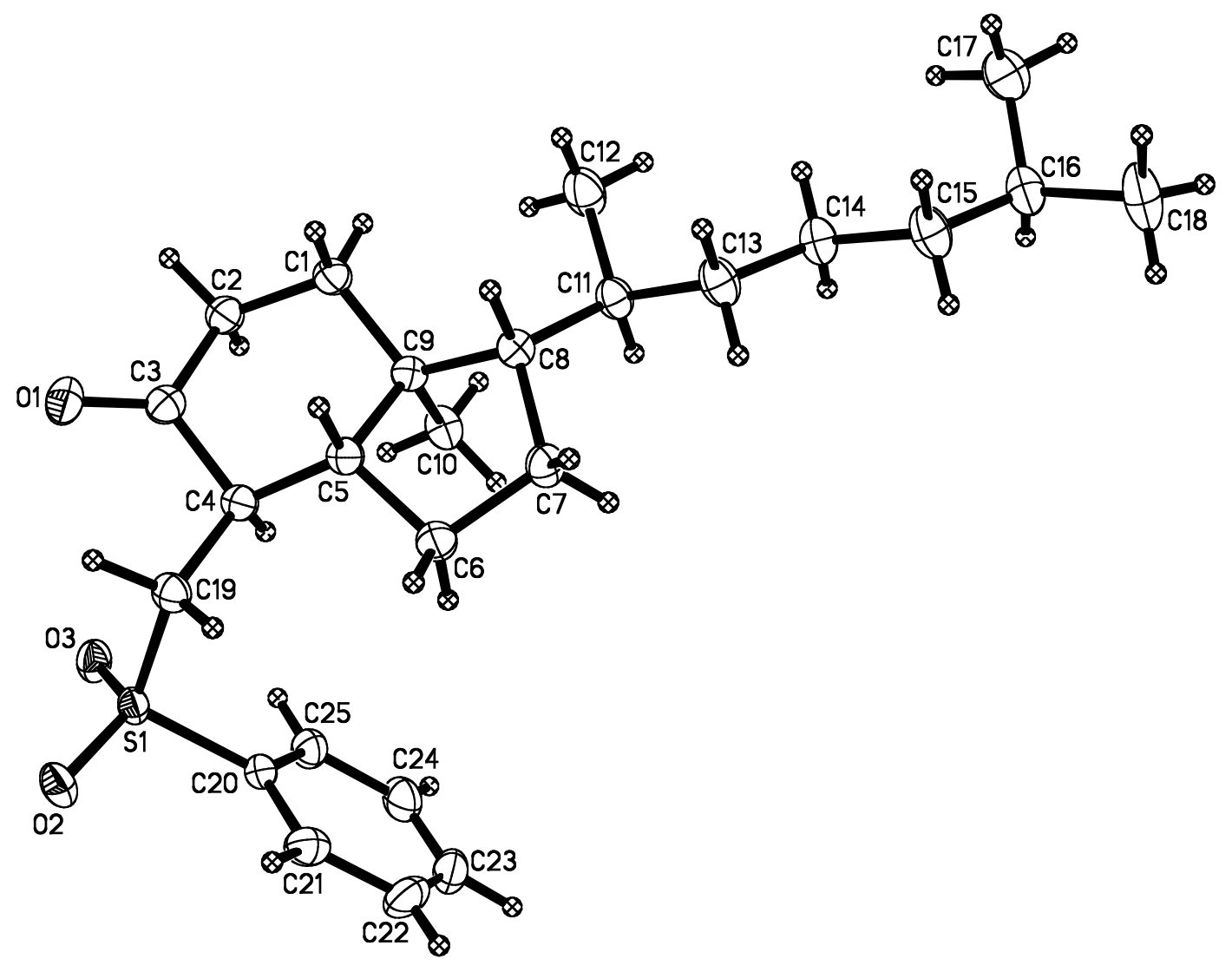


Belani and Rychnovsky

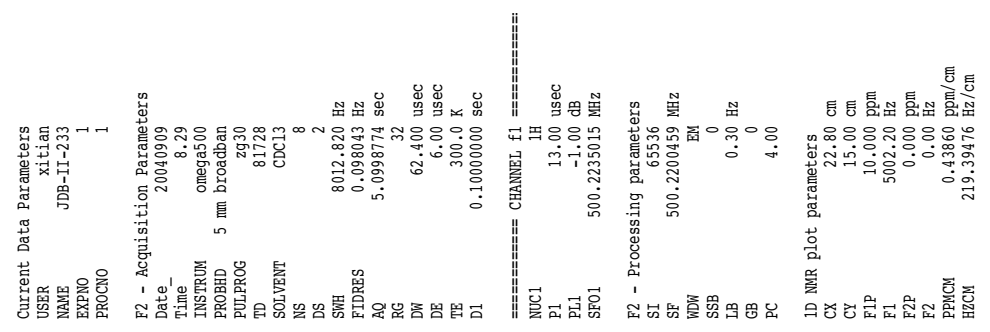

Page S18
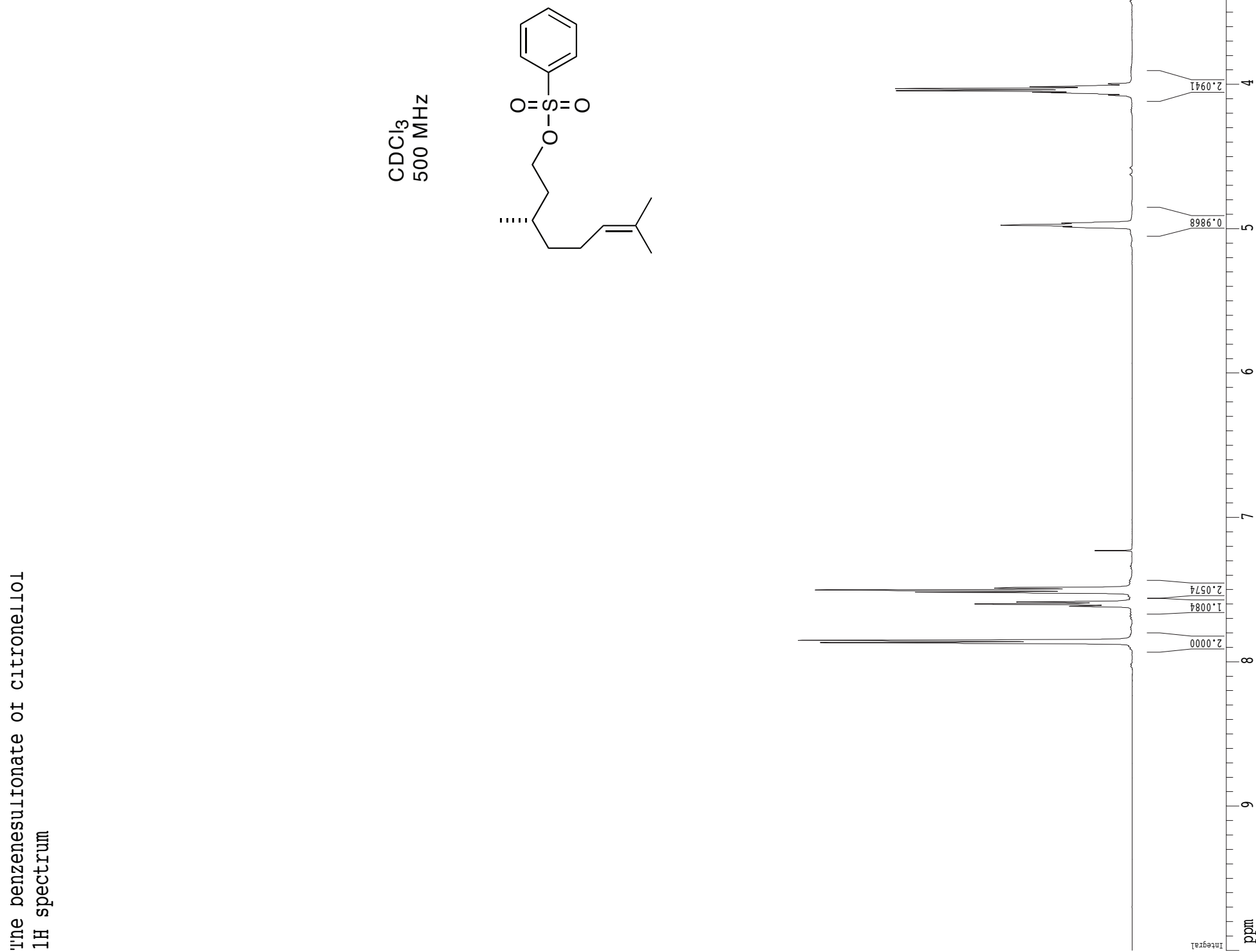
Belani and Rychnovsky

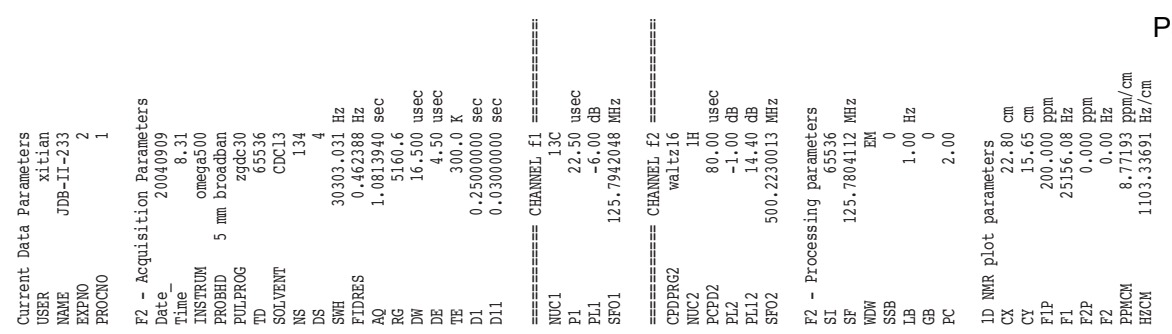

Page S19

$\frac{m}{\stackrel{N}{N}}$

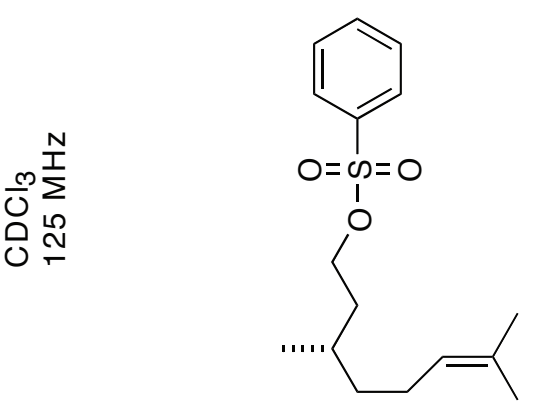




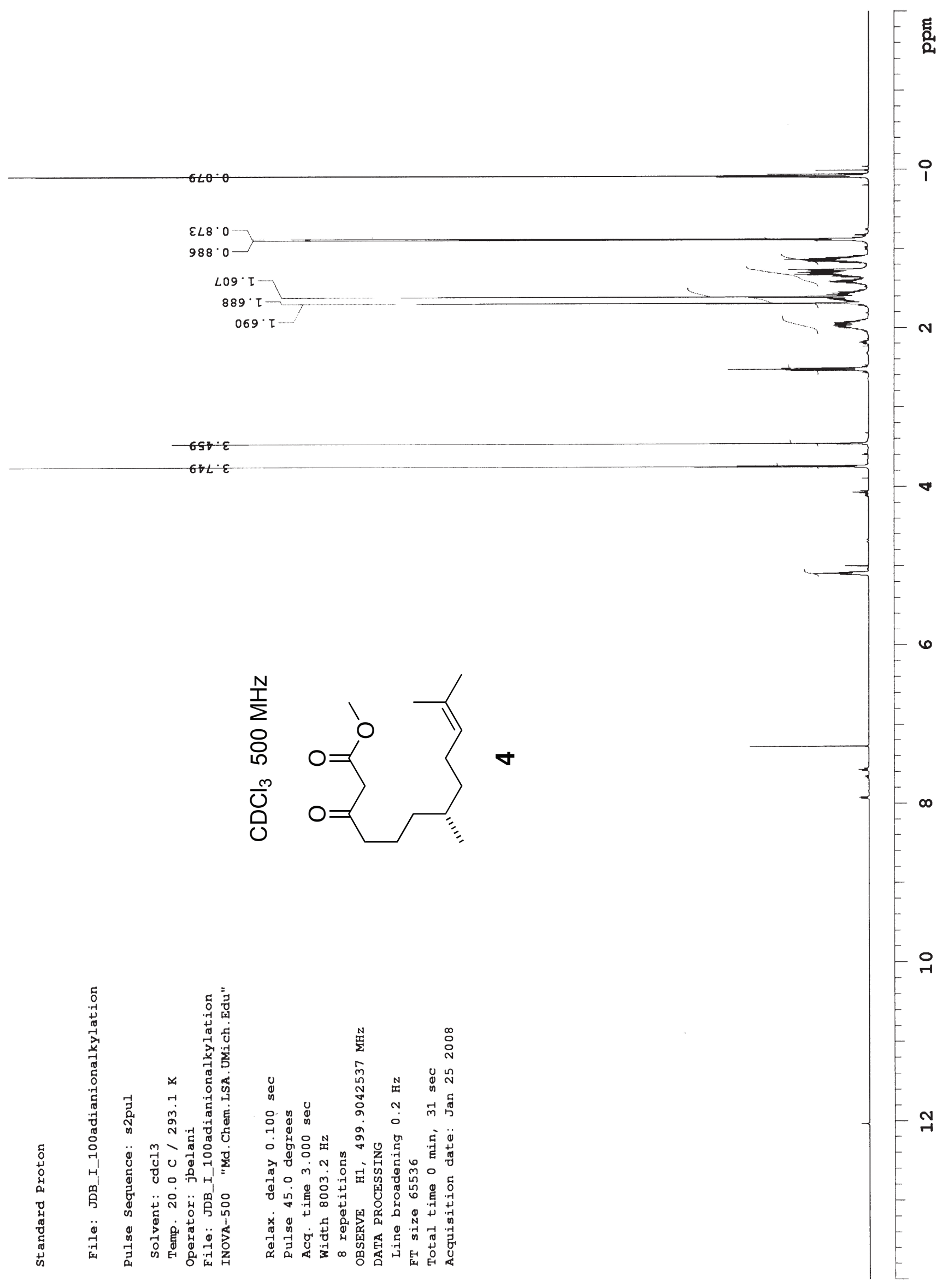




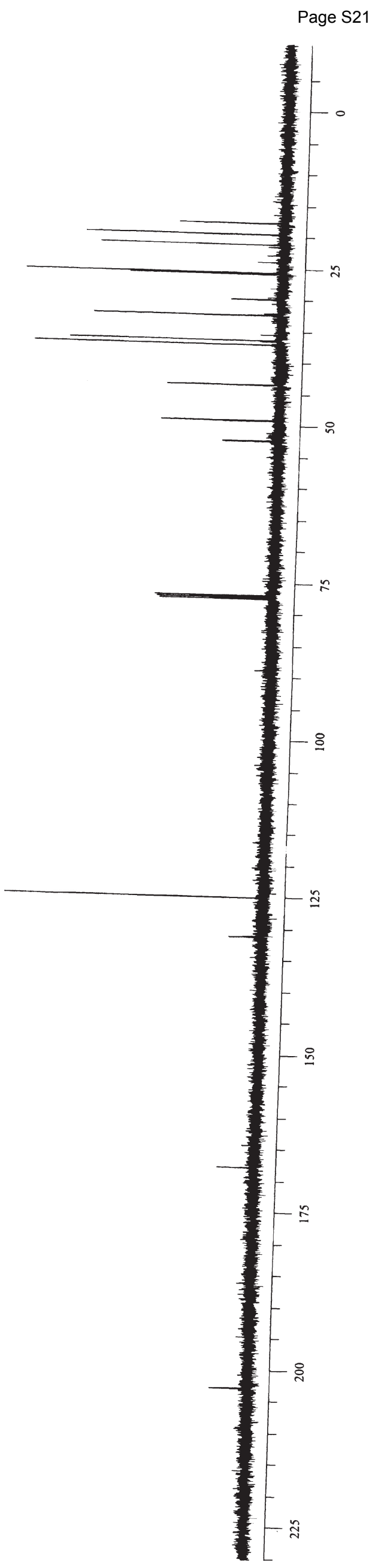



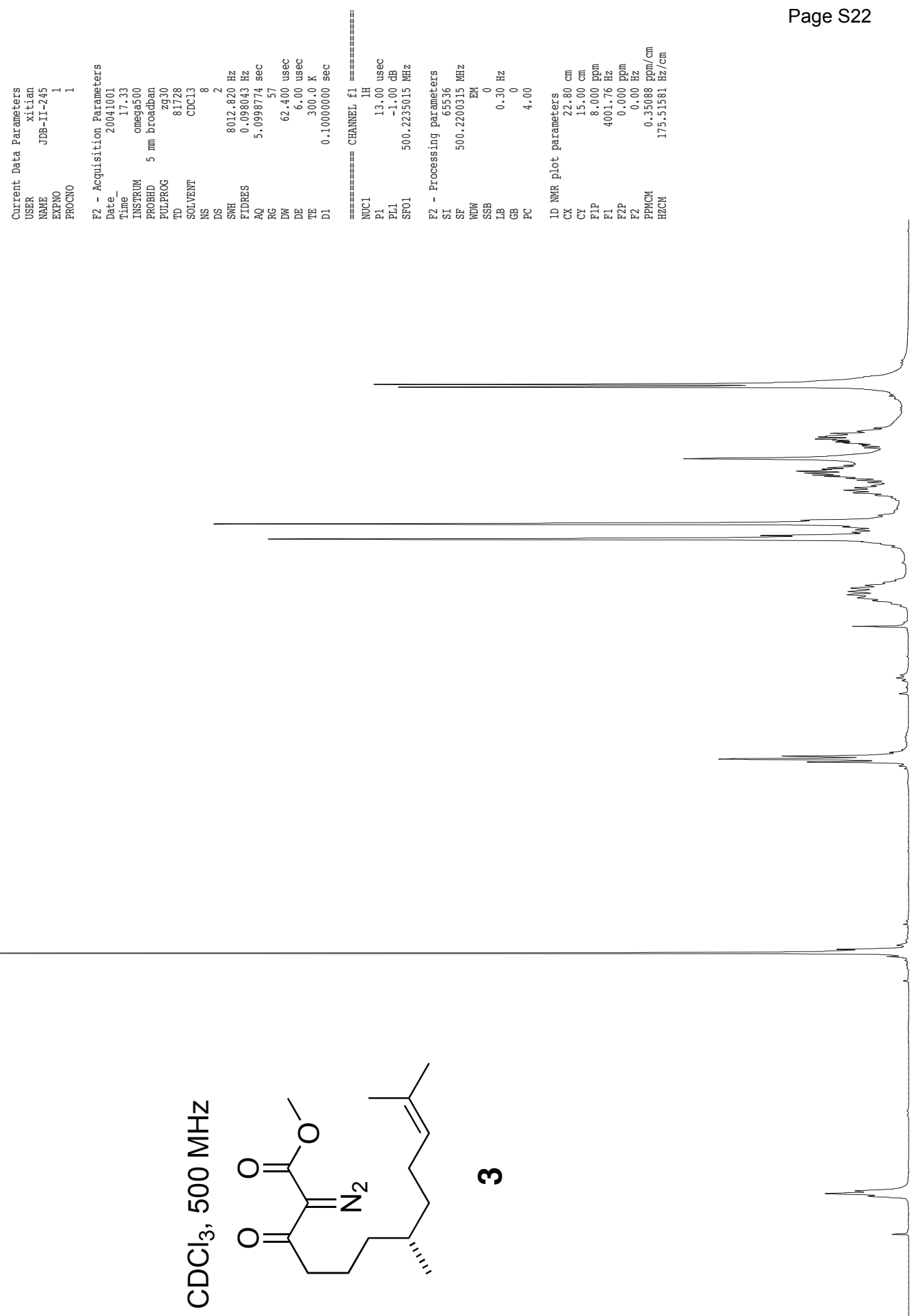
Belani and Rychnovsky

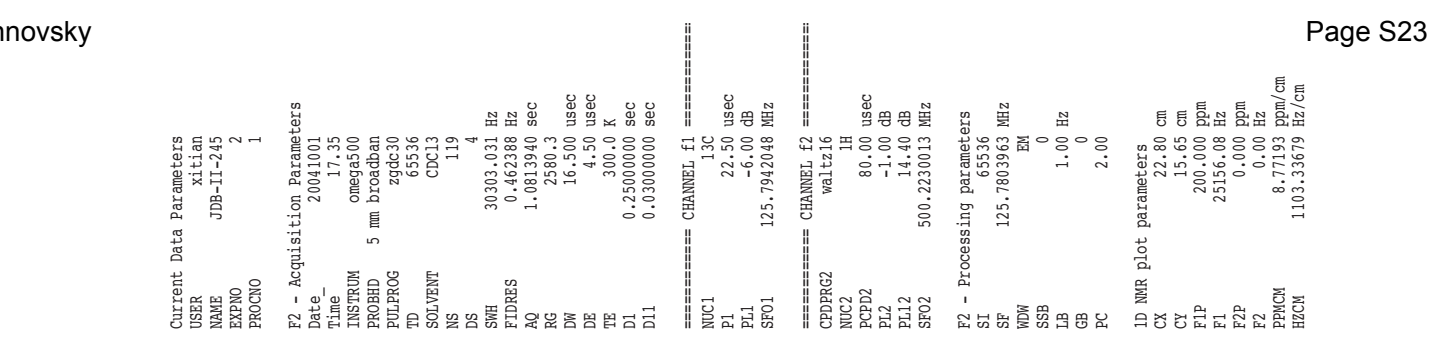

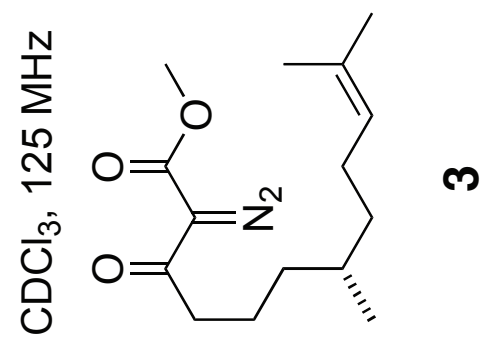



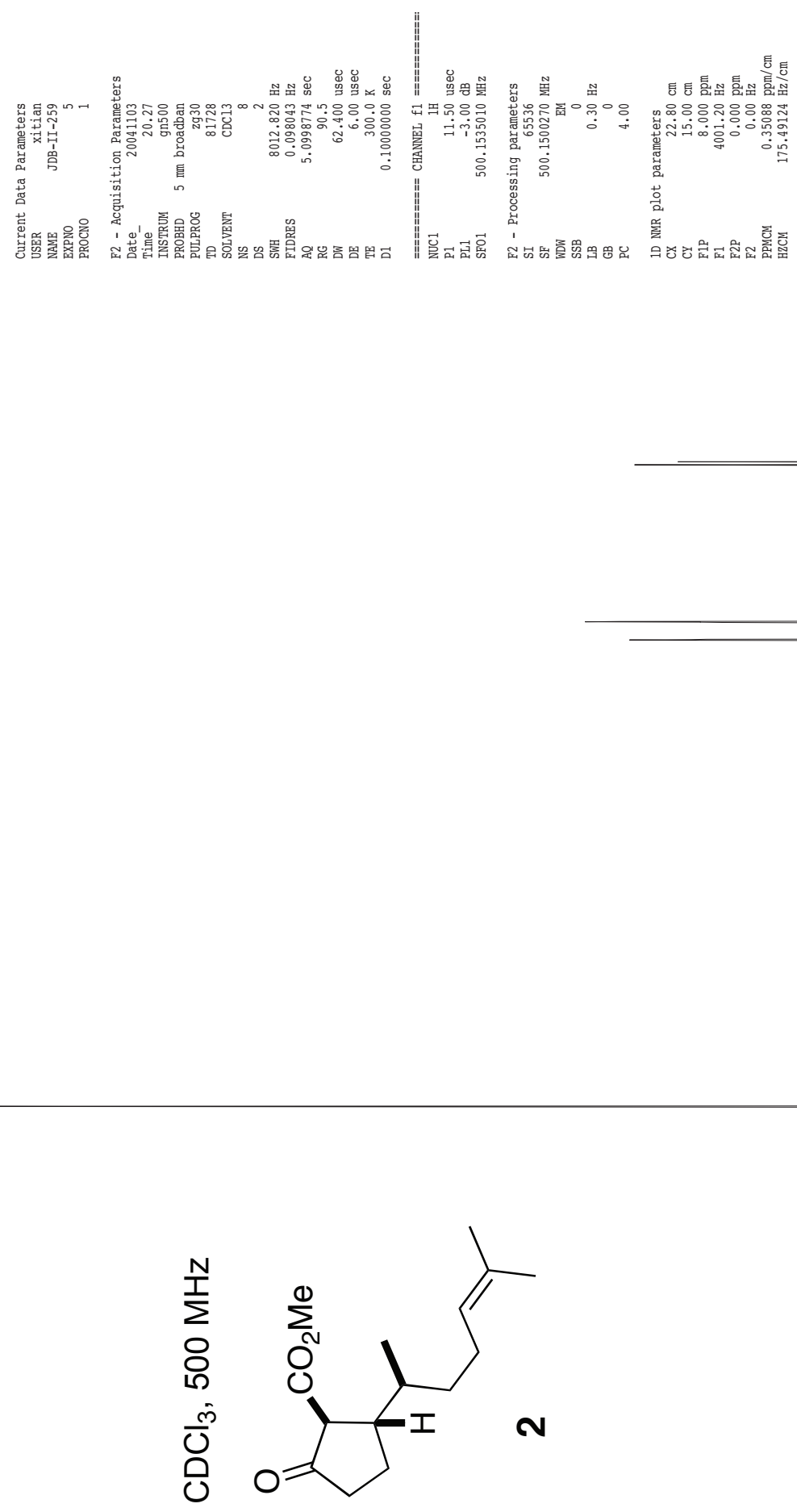

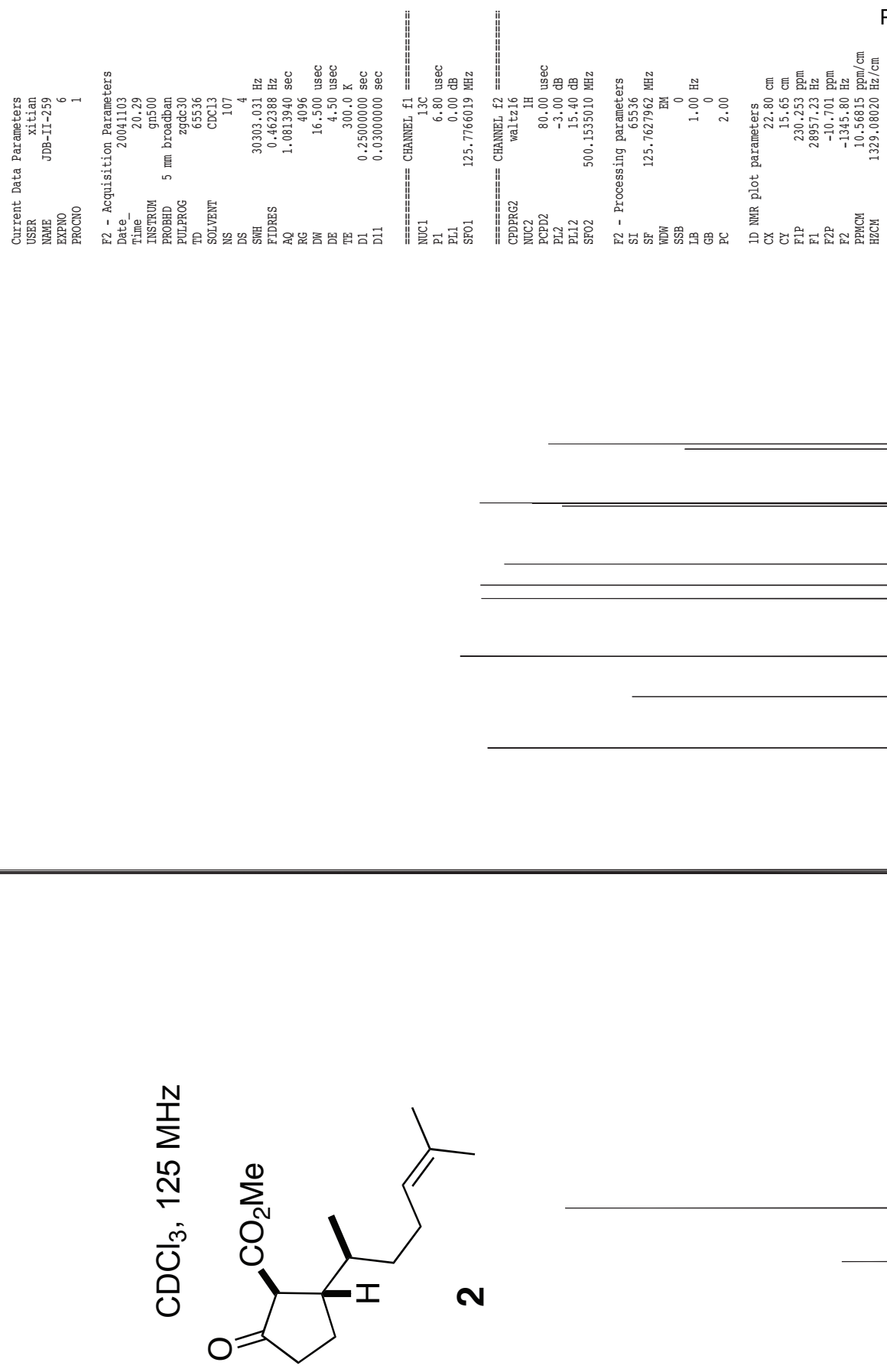

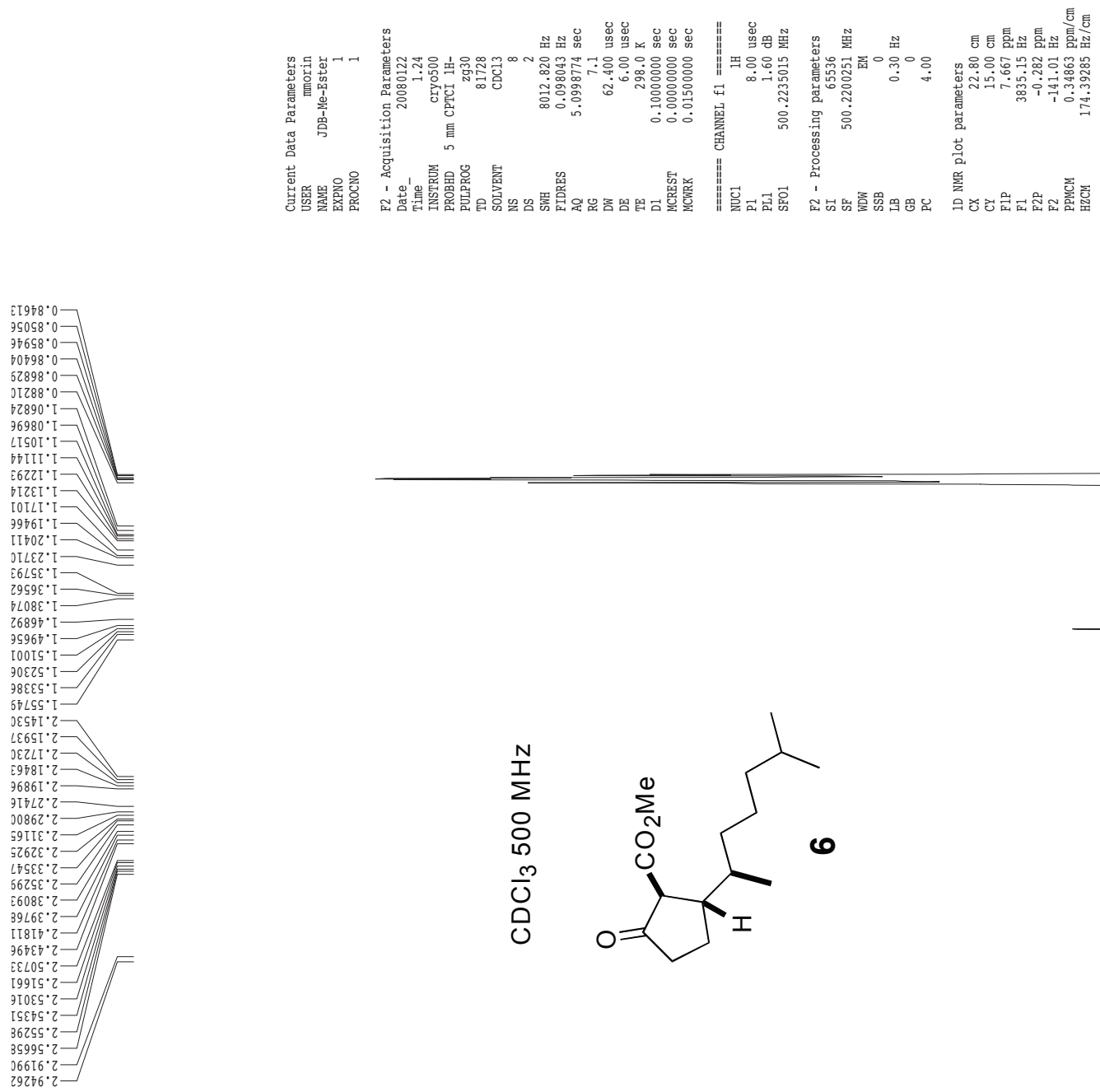

$3862 L^{\circ} \varepsilon$
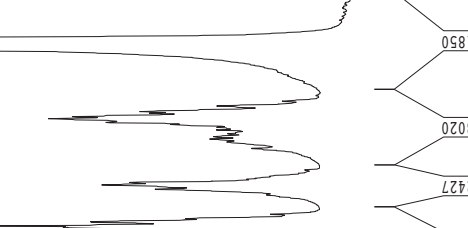

$\angle 2 \hbar \tau^{\circ} \cdot \overline{2}$
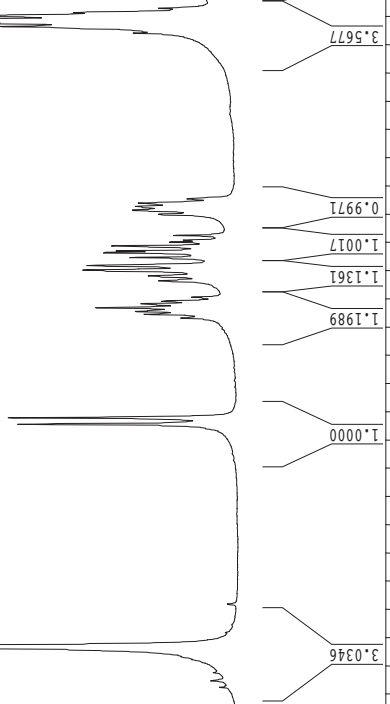

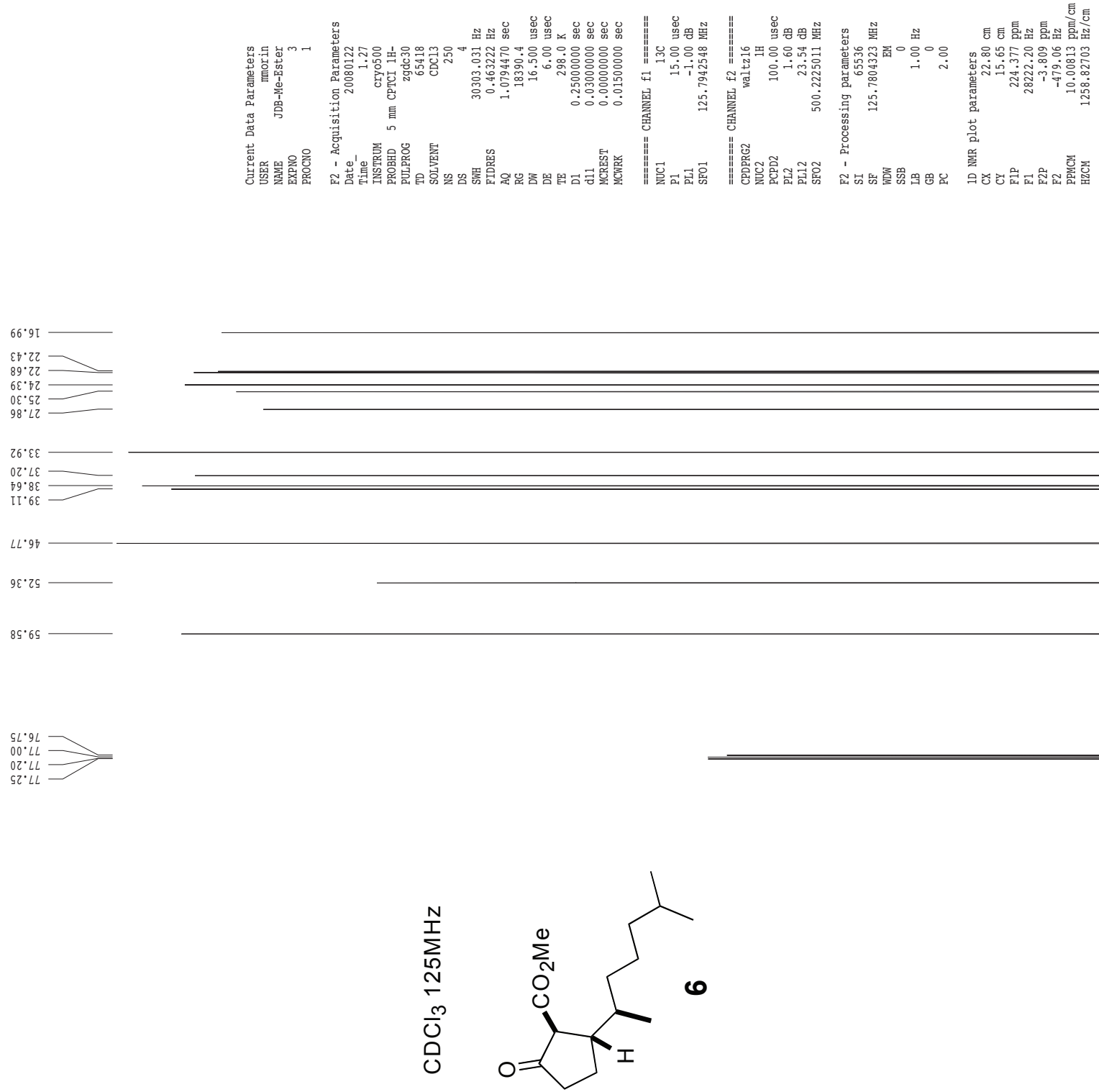

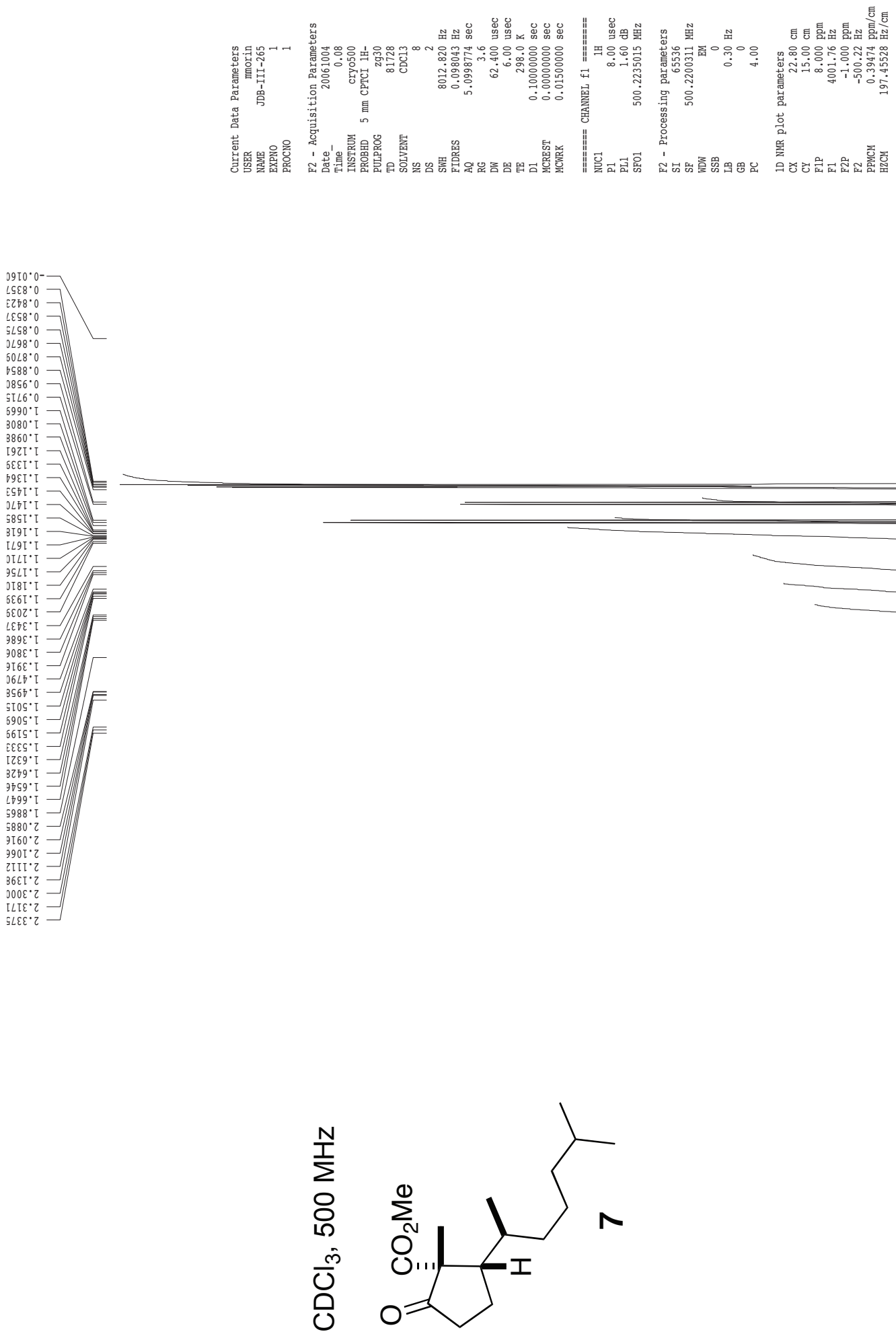

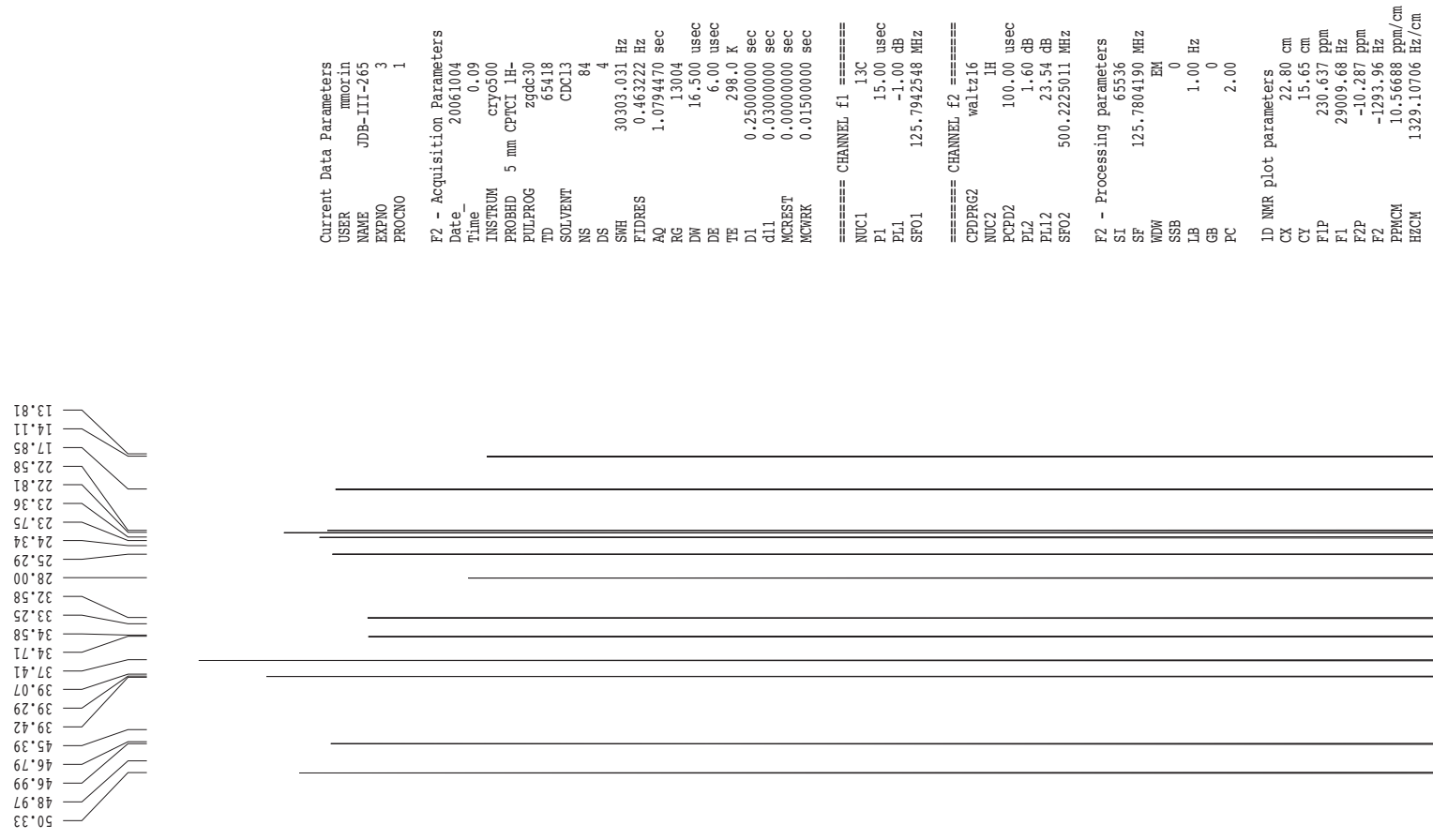

$\varepsilon 8^{\circ} \cdot 9 L$
$60 . \angle L$
$\hbar \varepsilon \cdot L L$

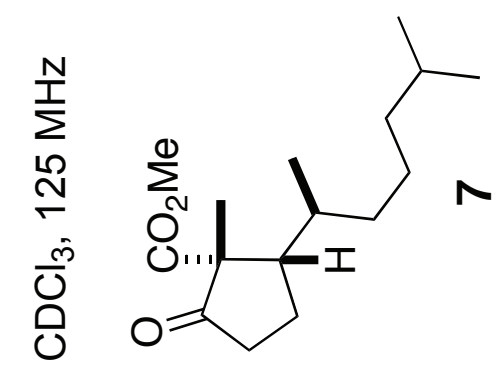



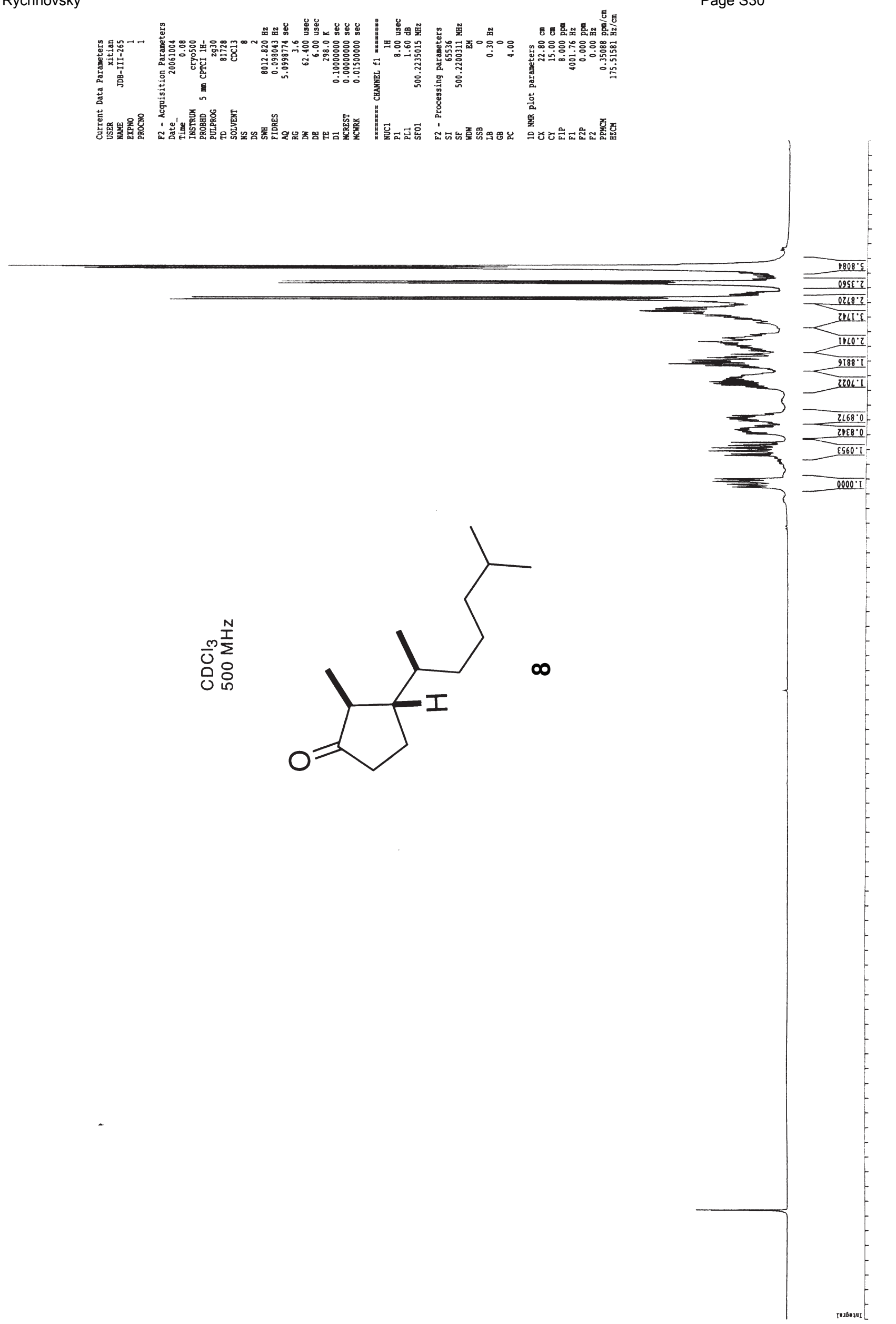

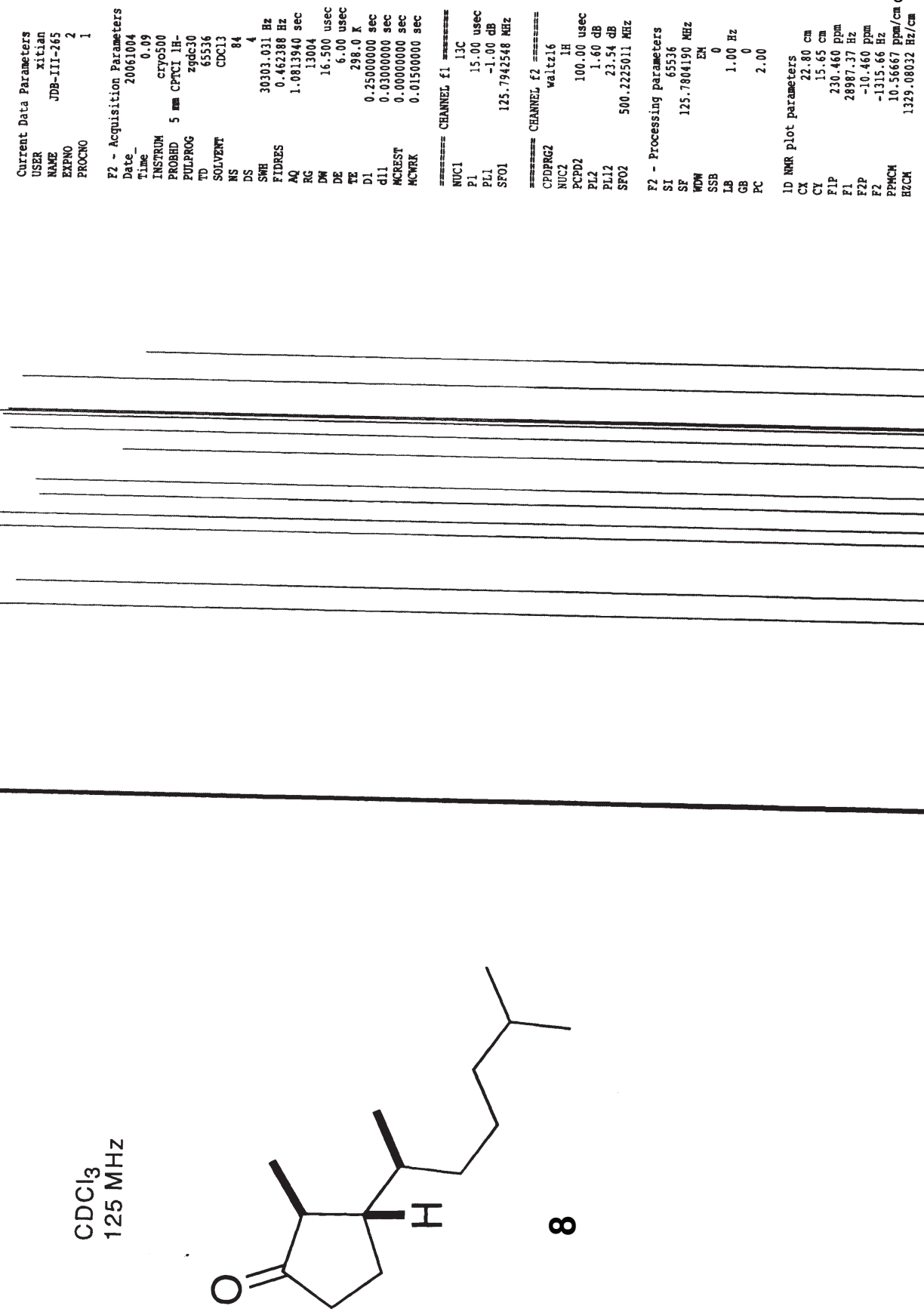

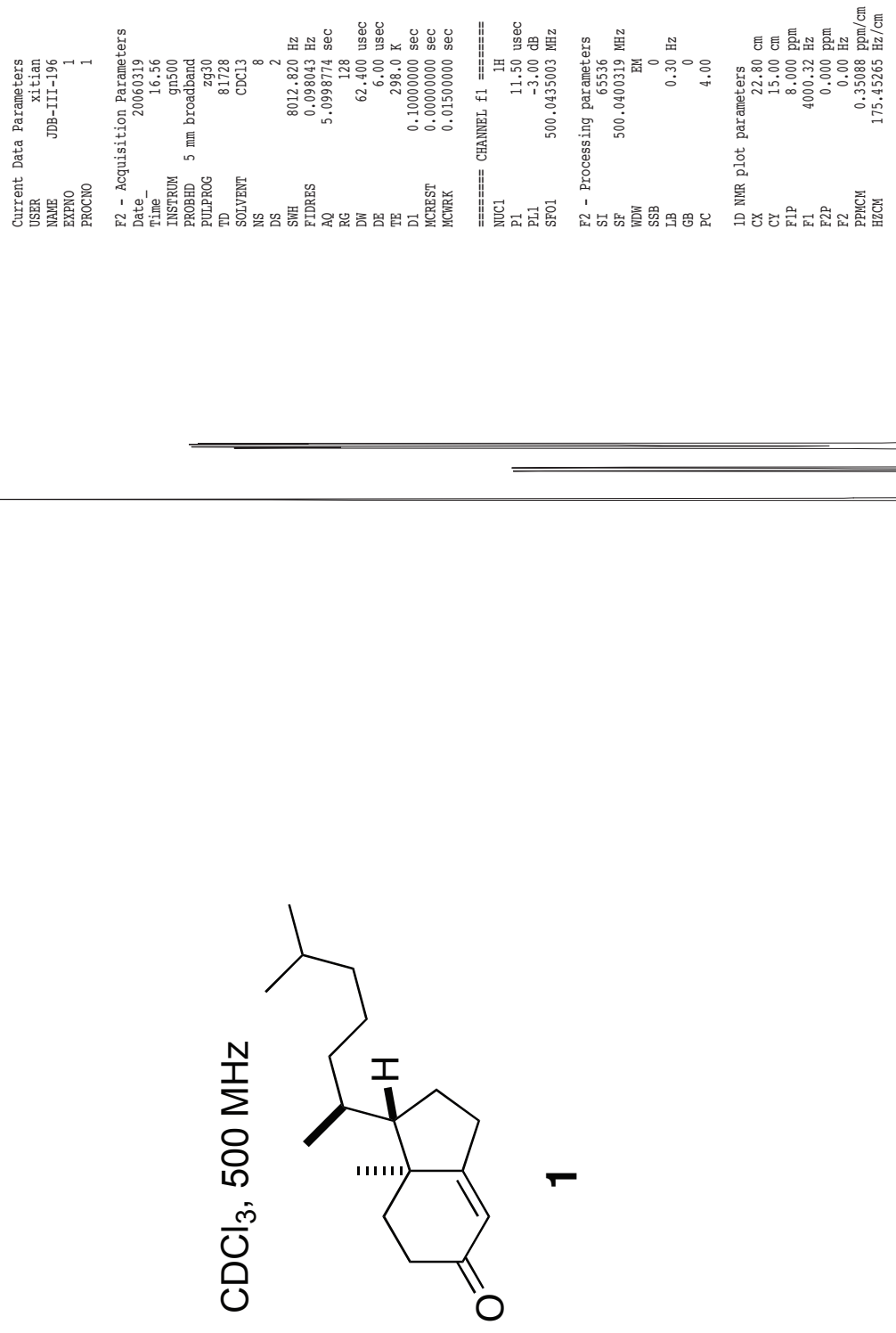

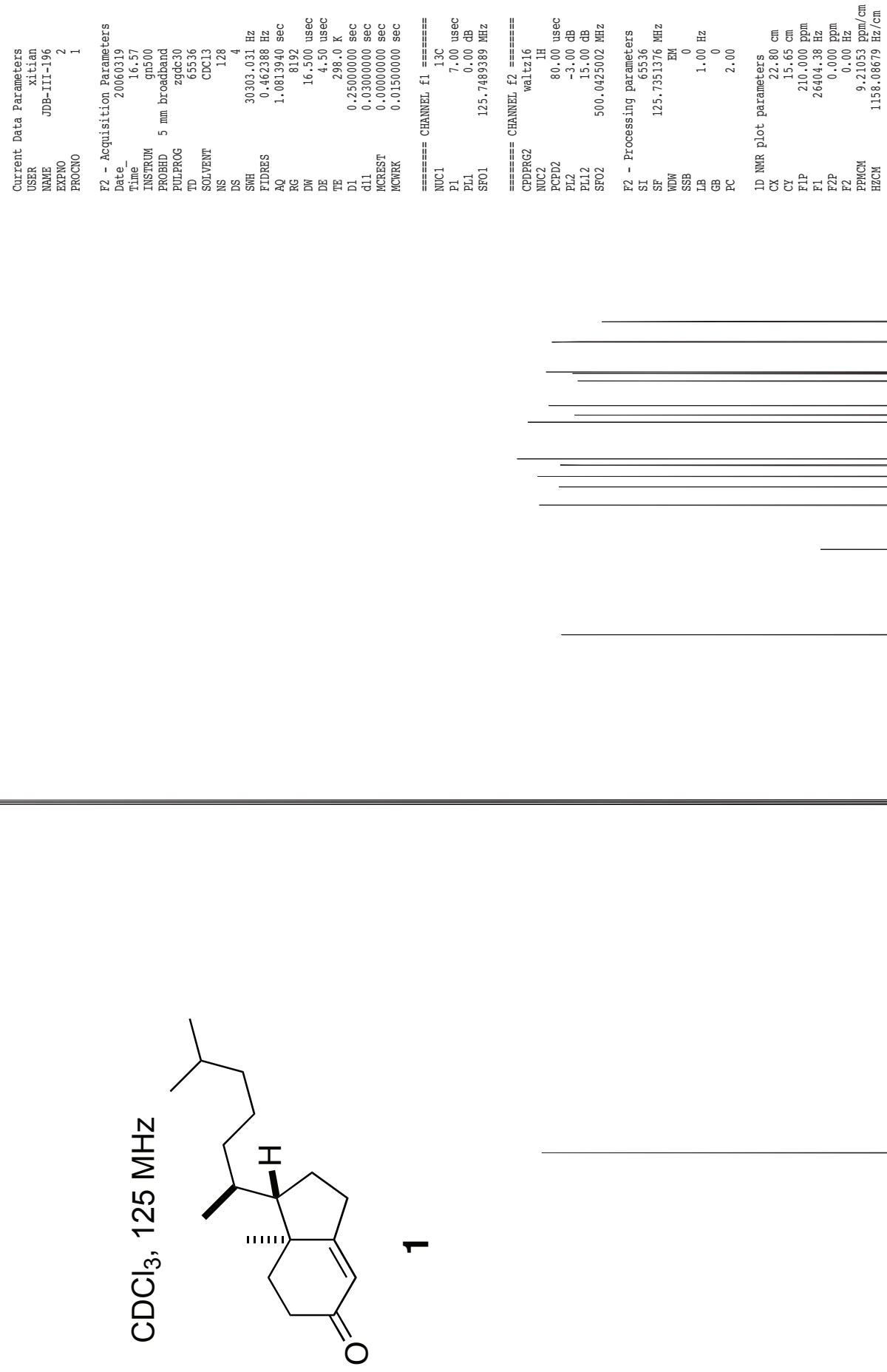

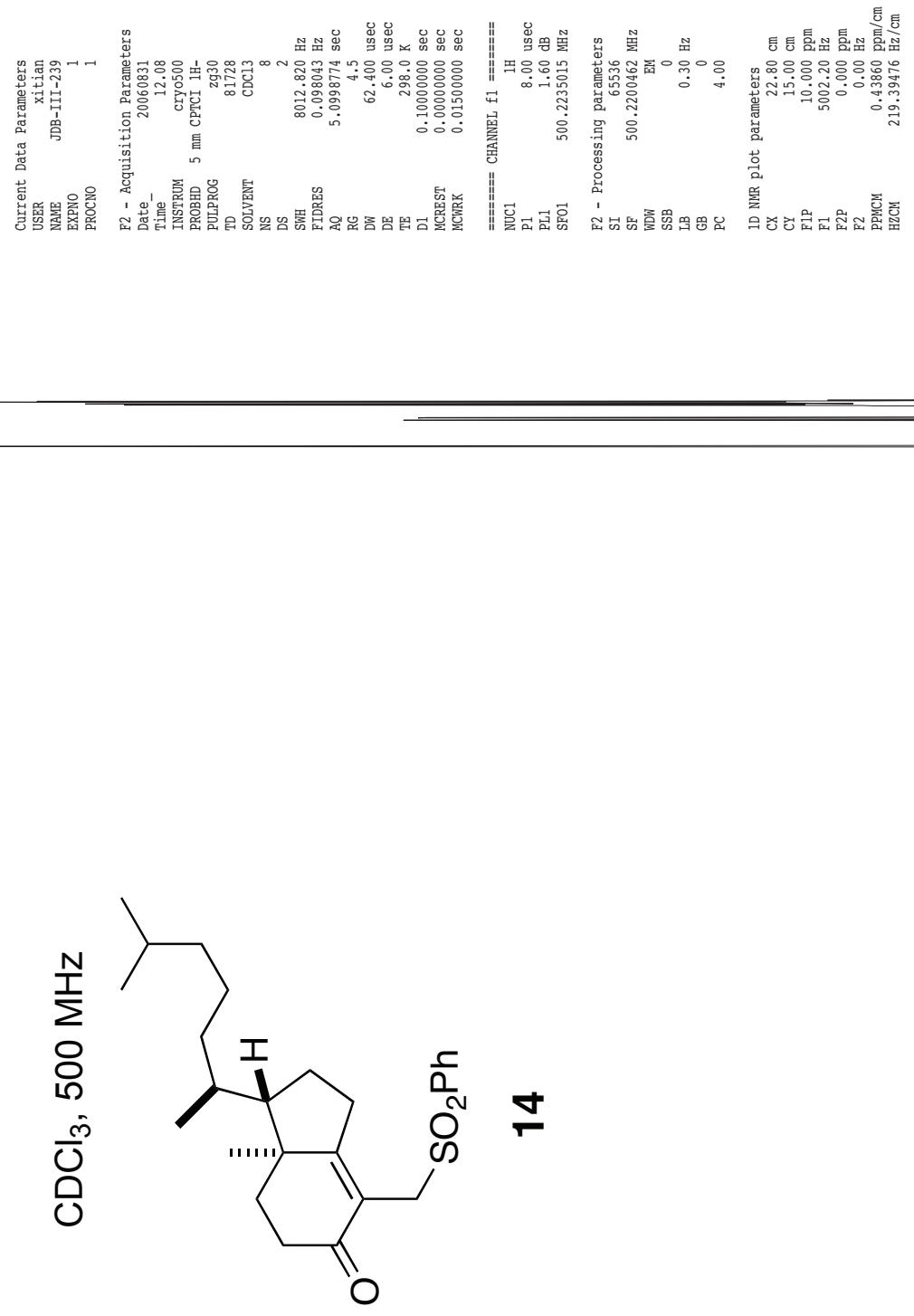

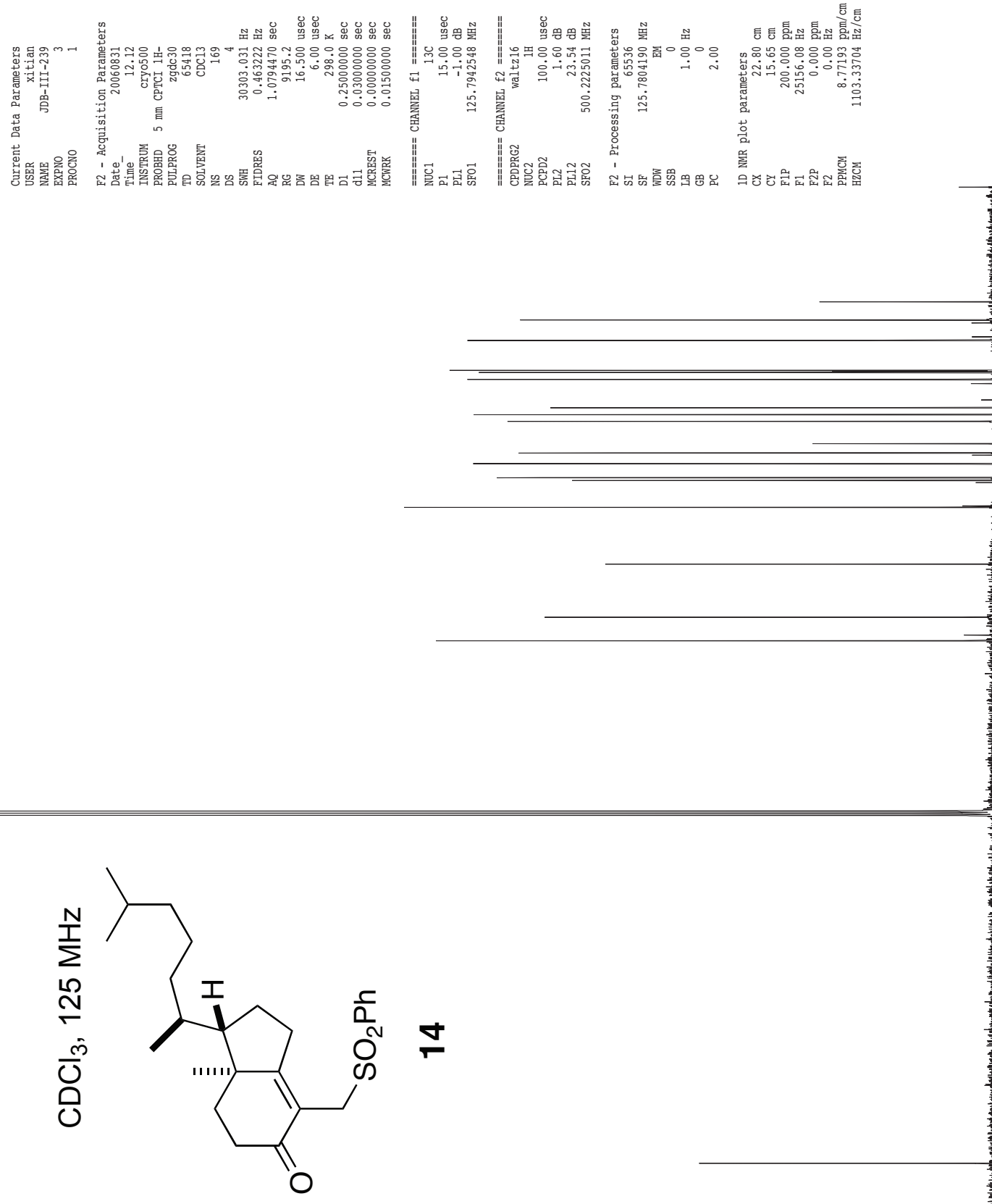

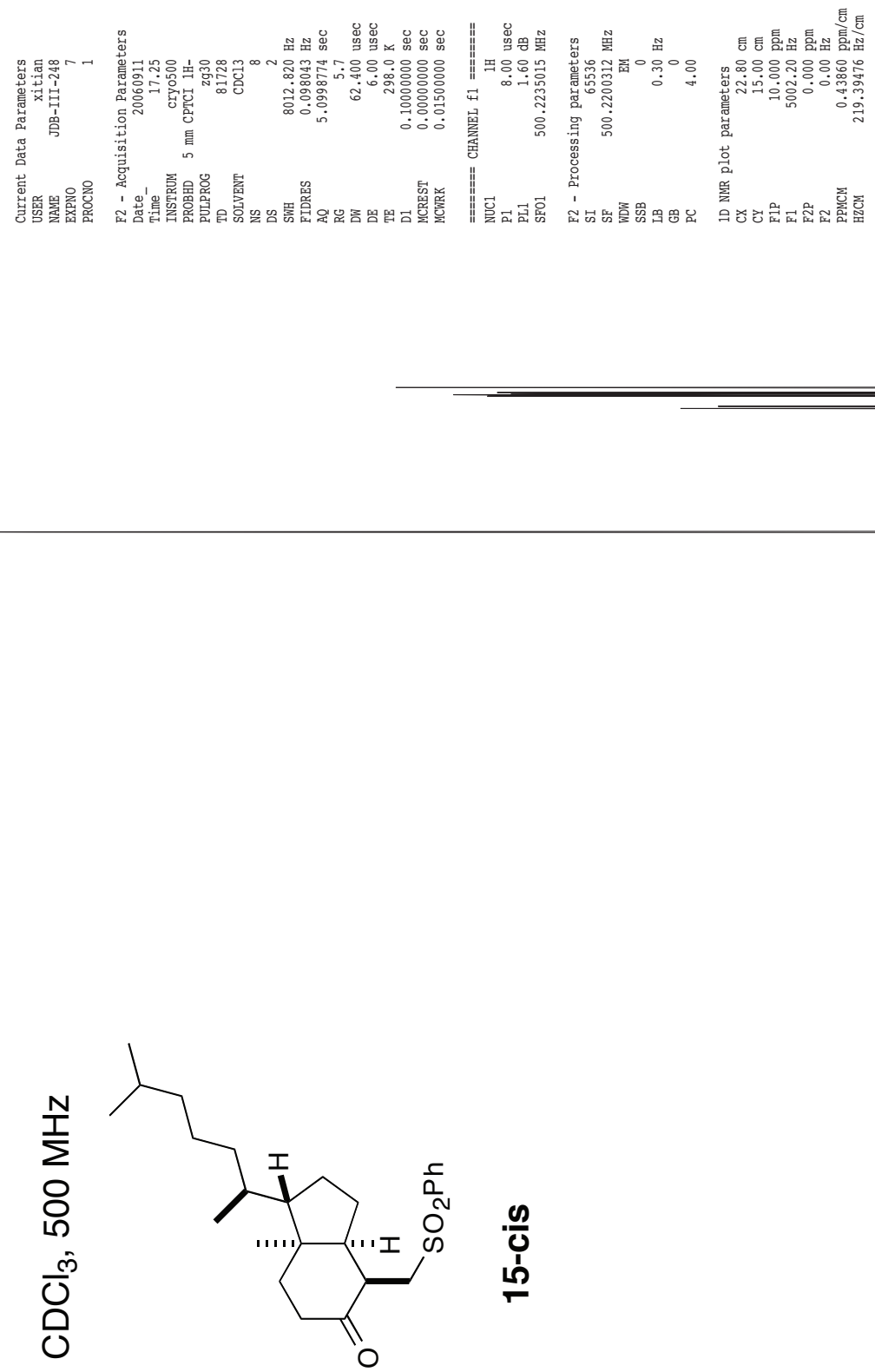

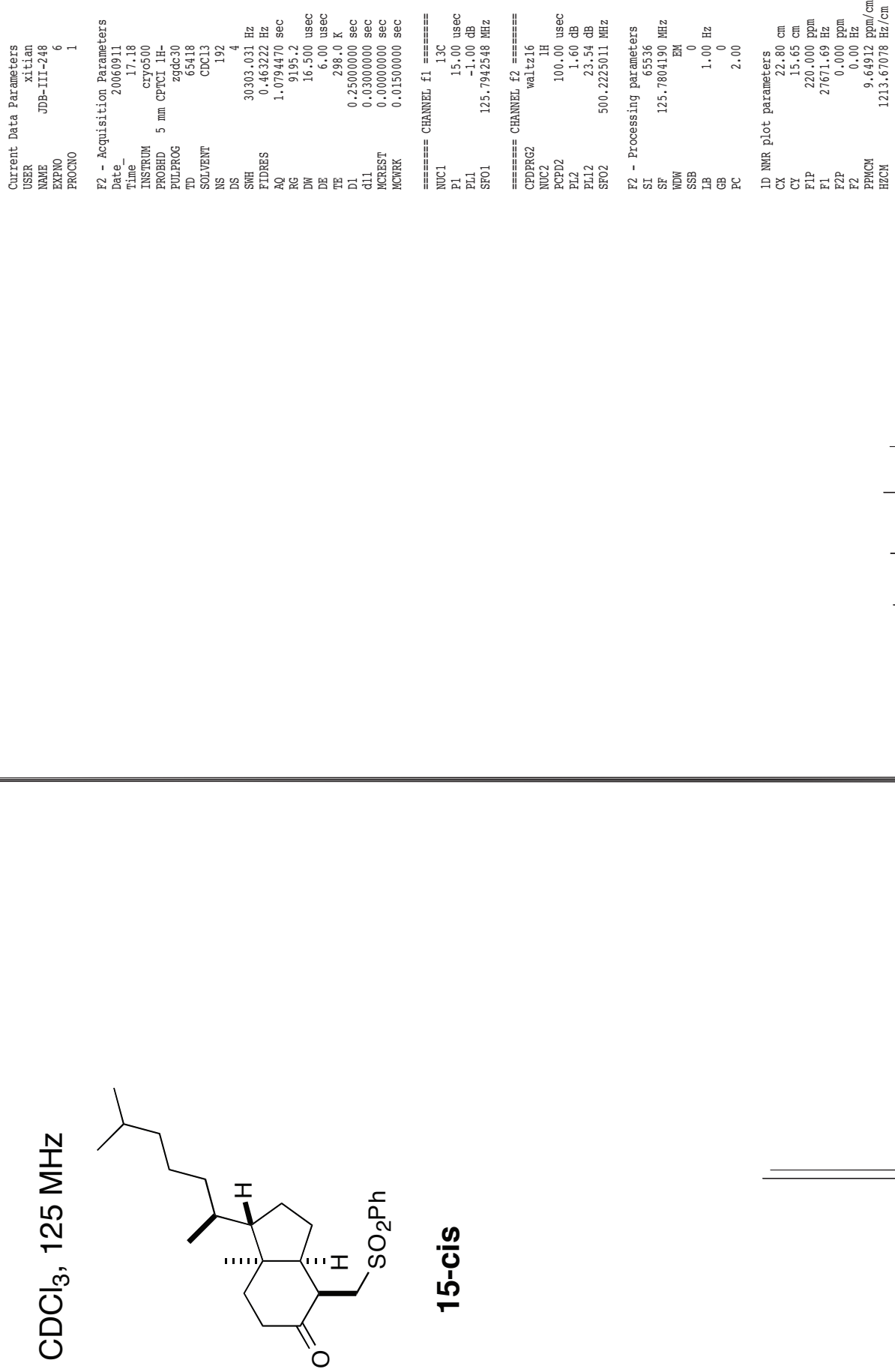

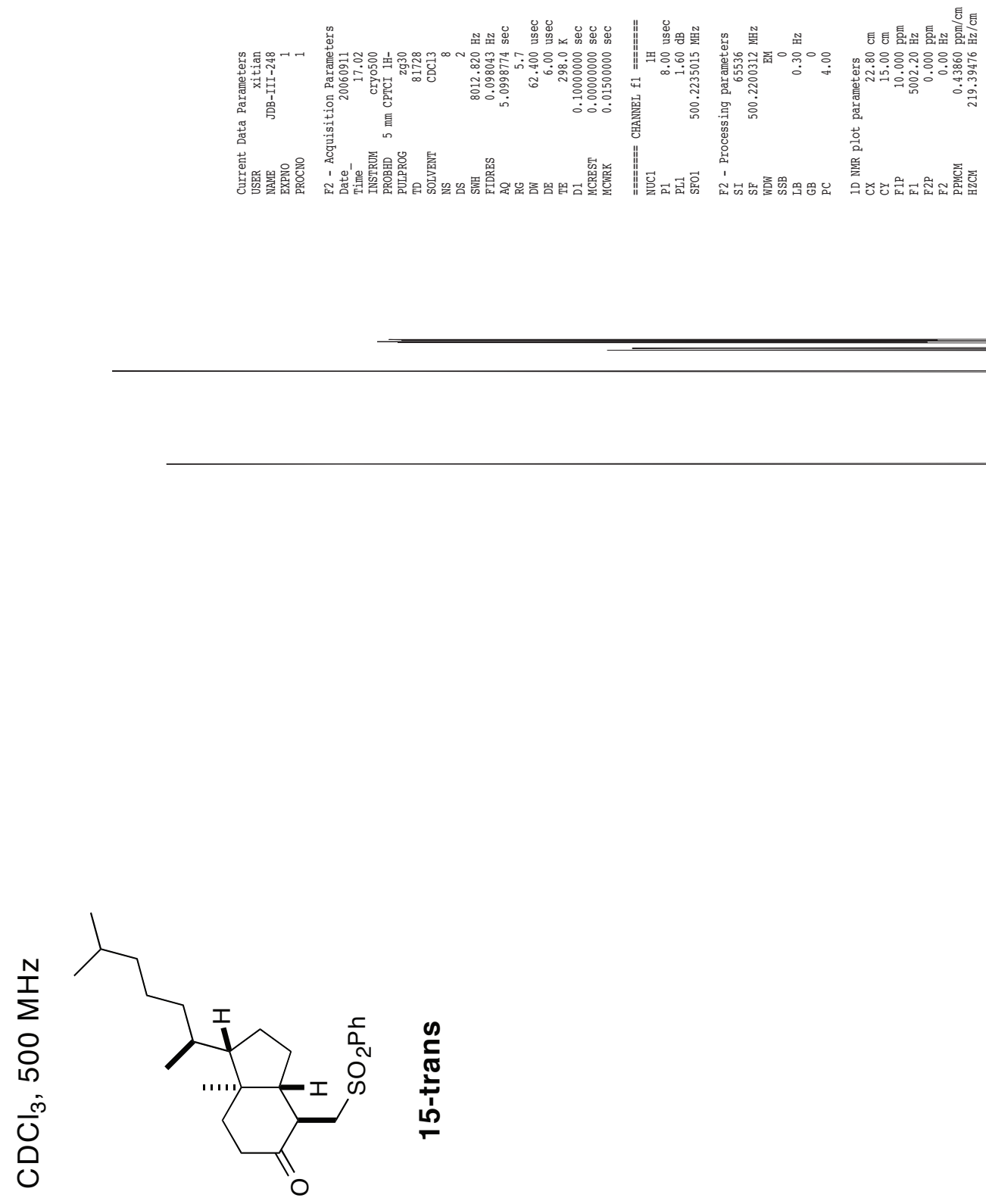

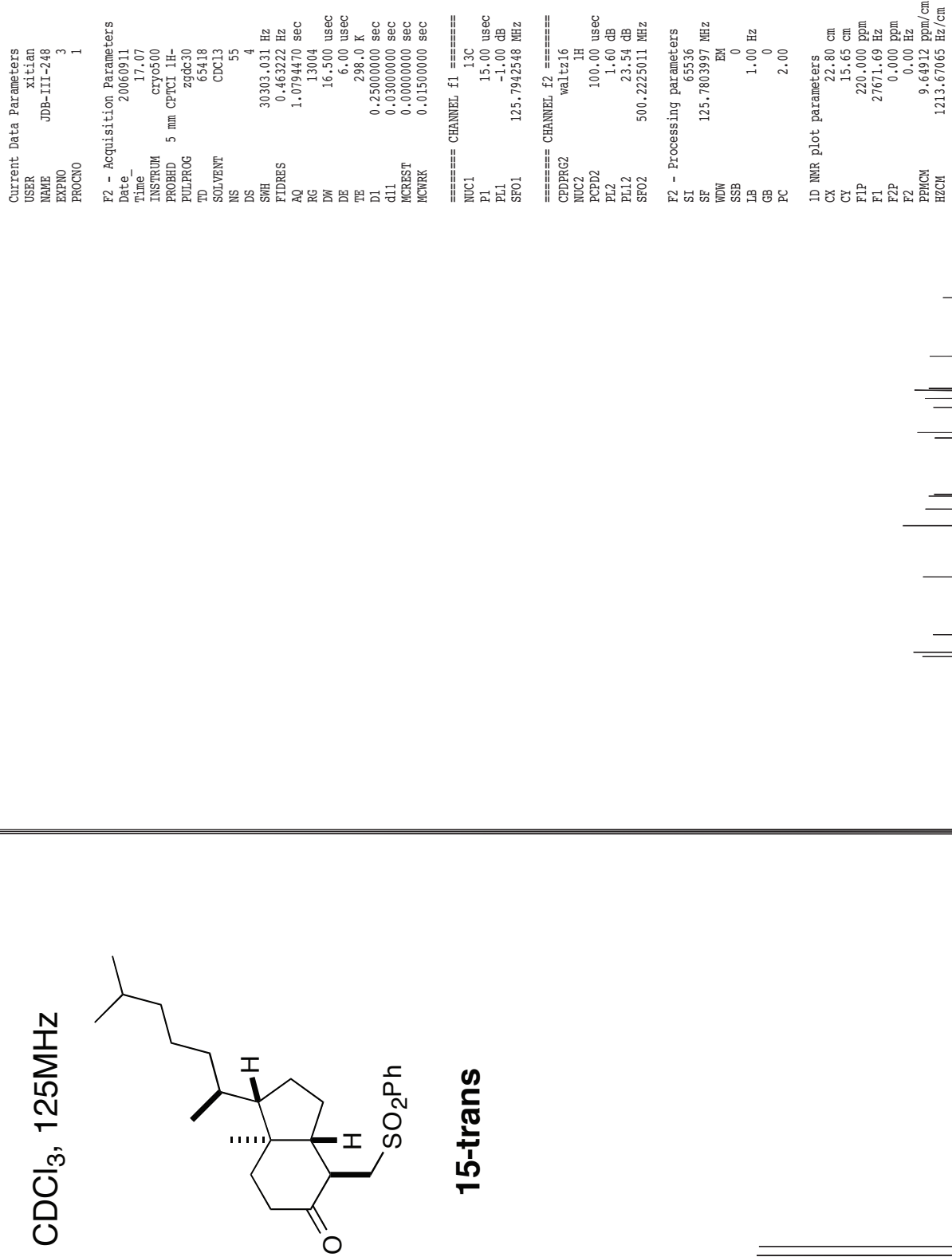

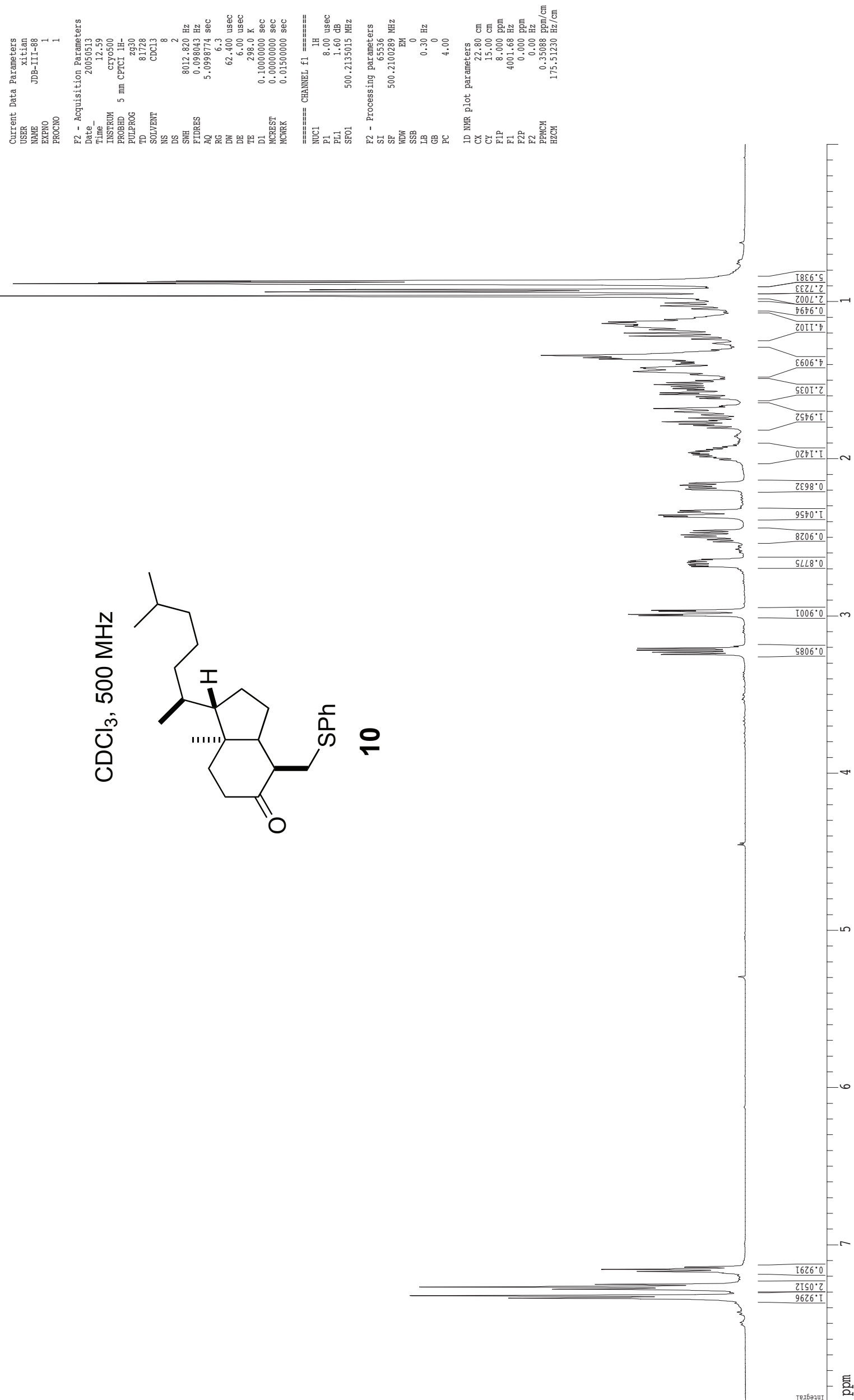

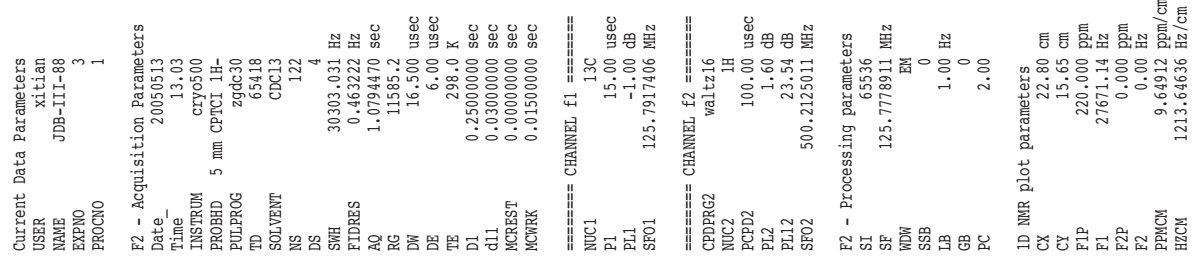

틀틀

|
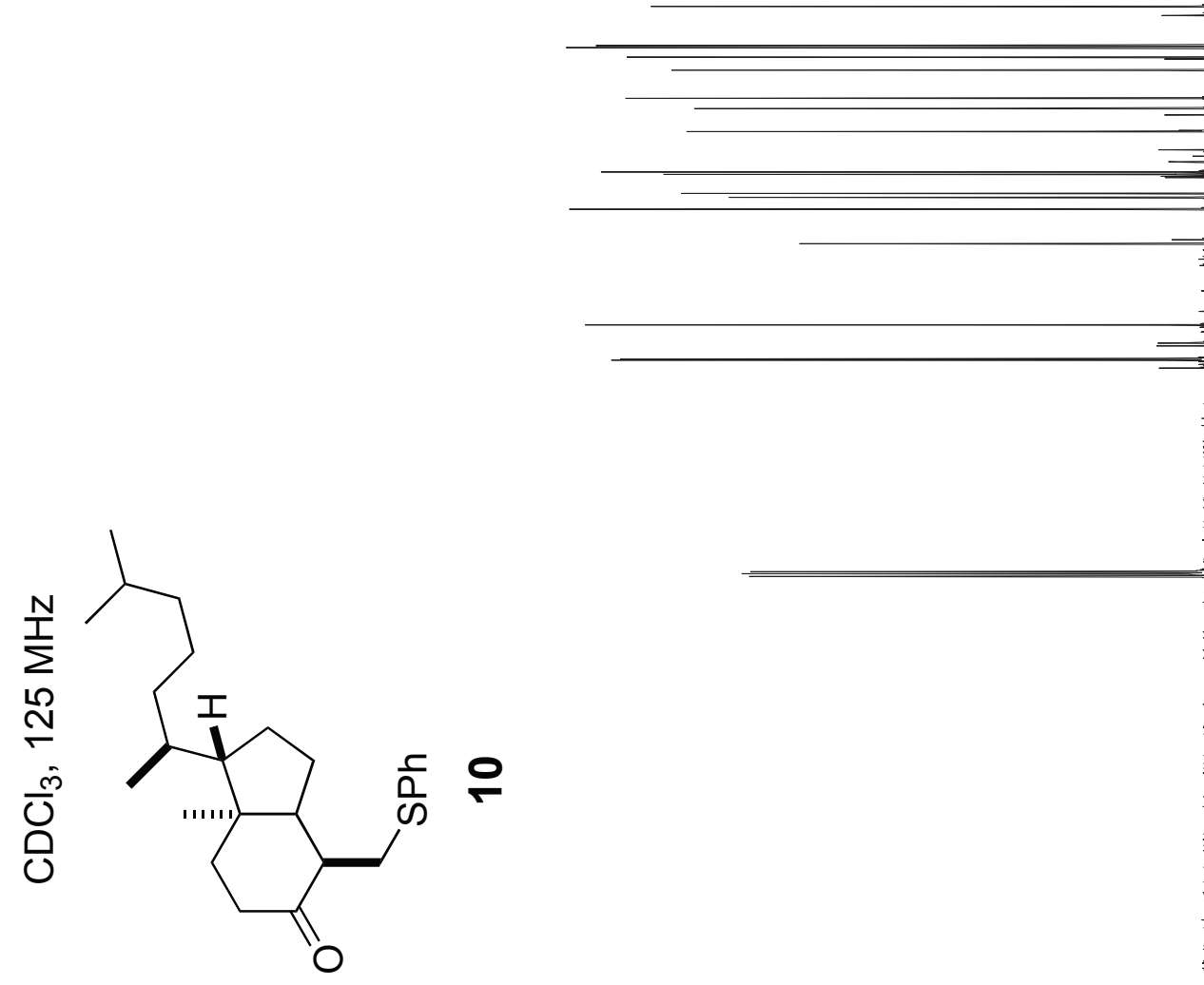

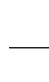

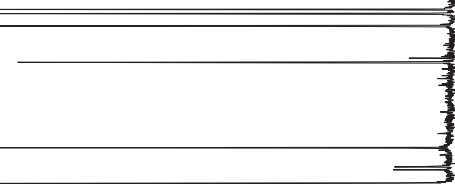




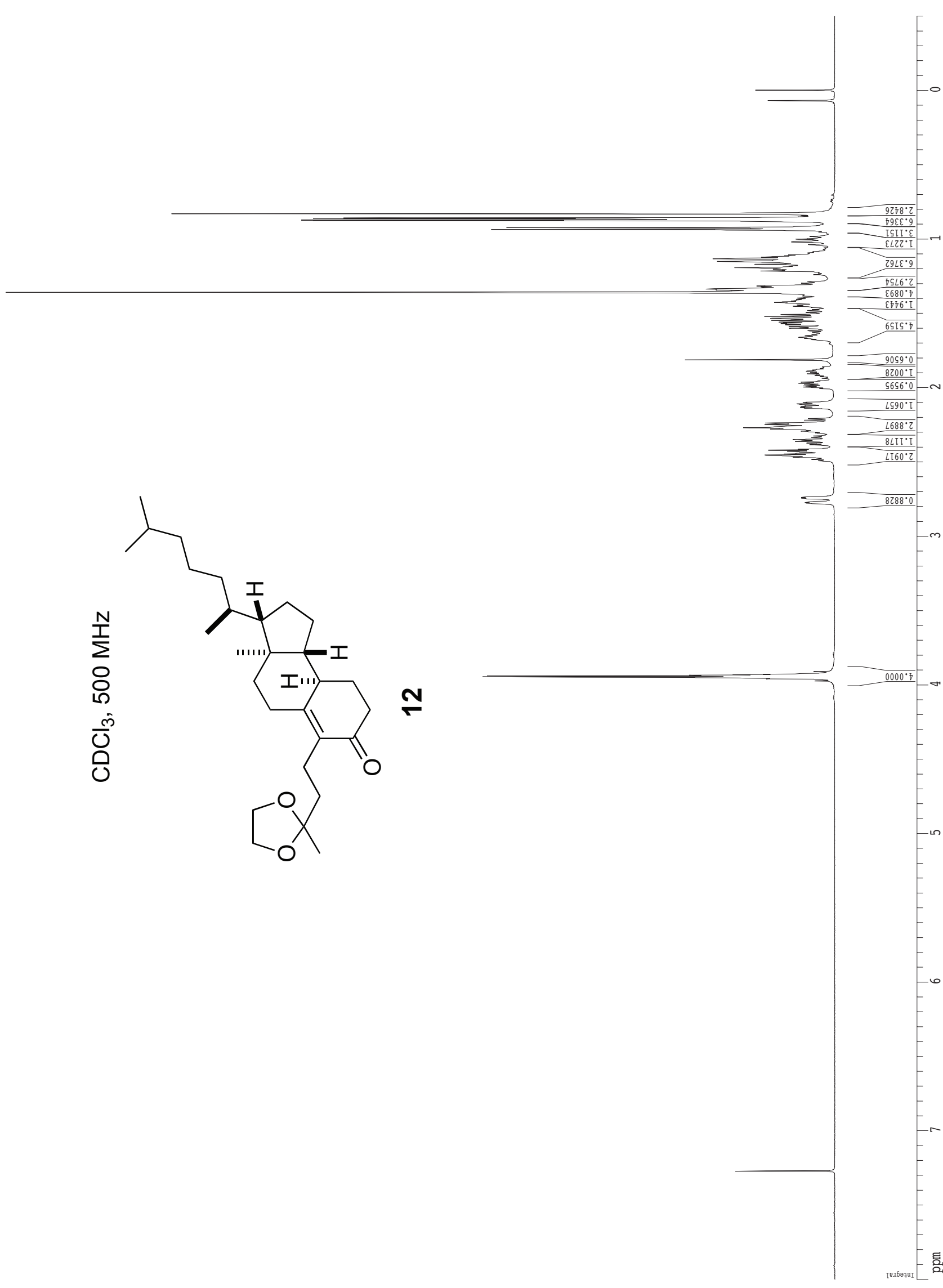




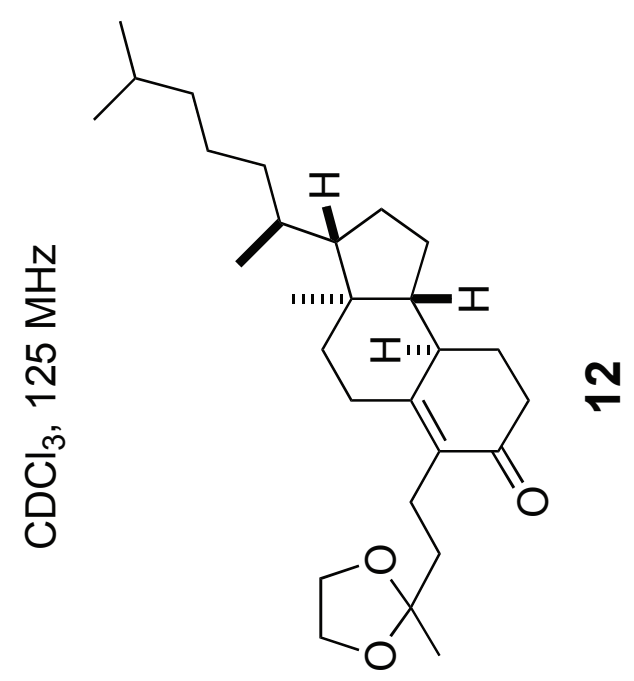



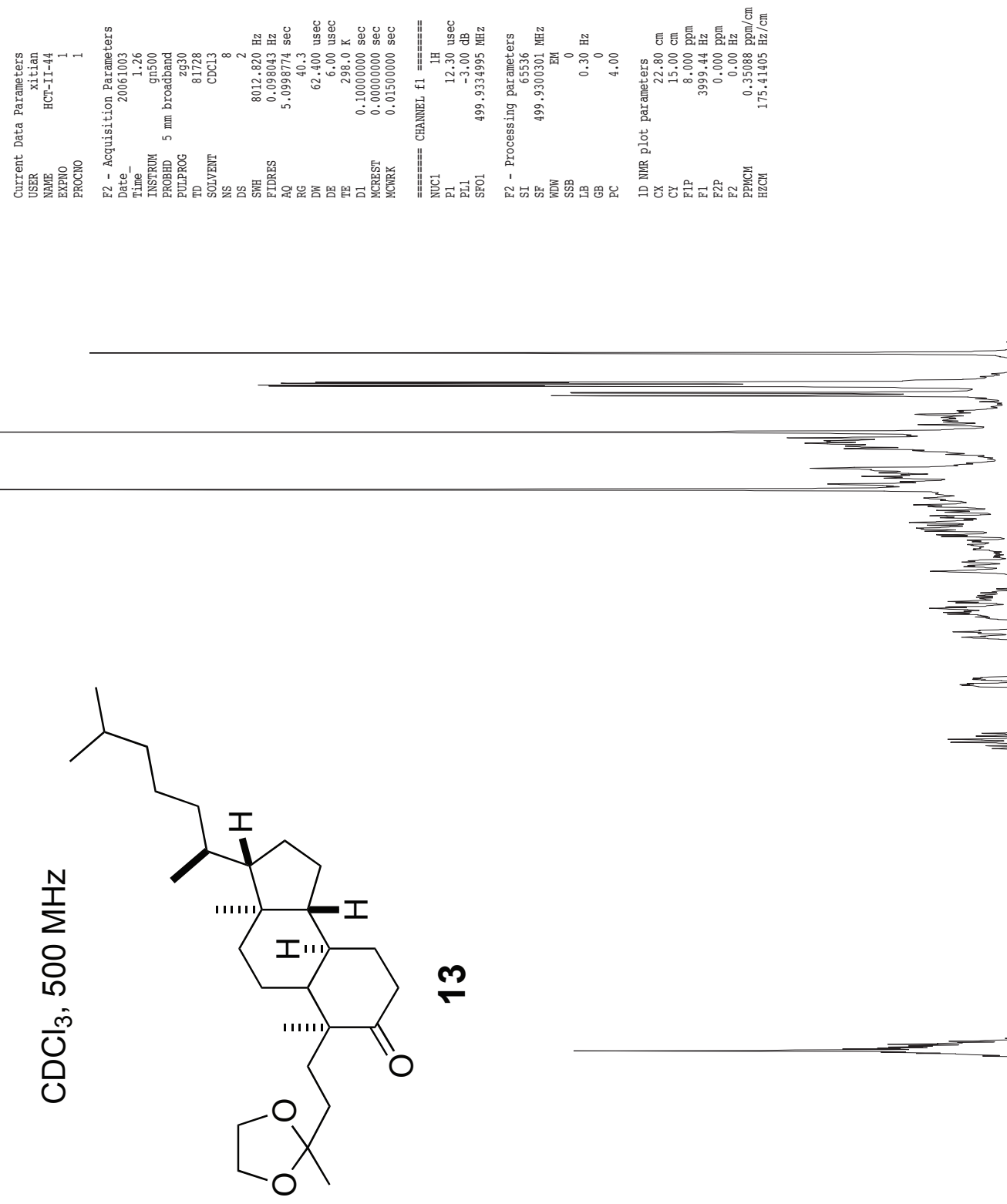

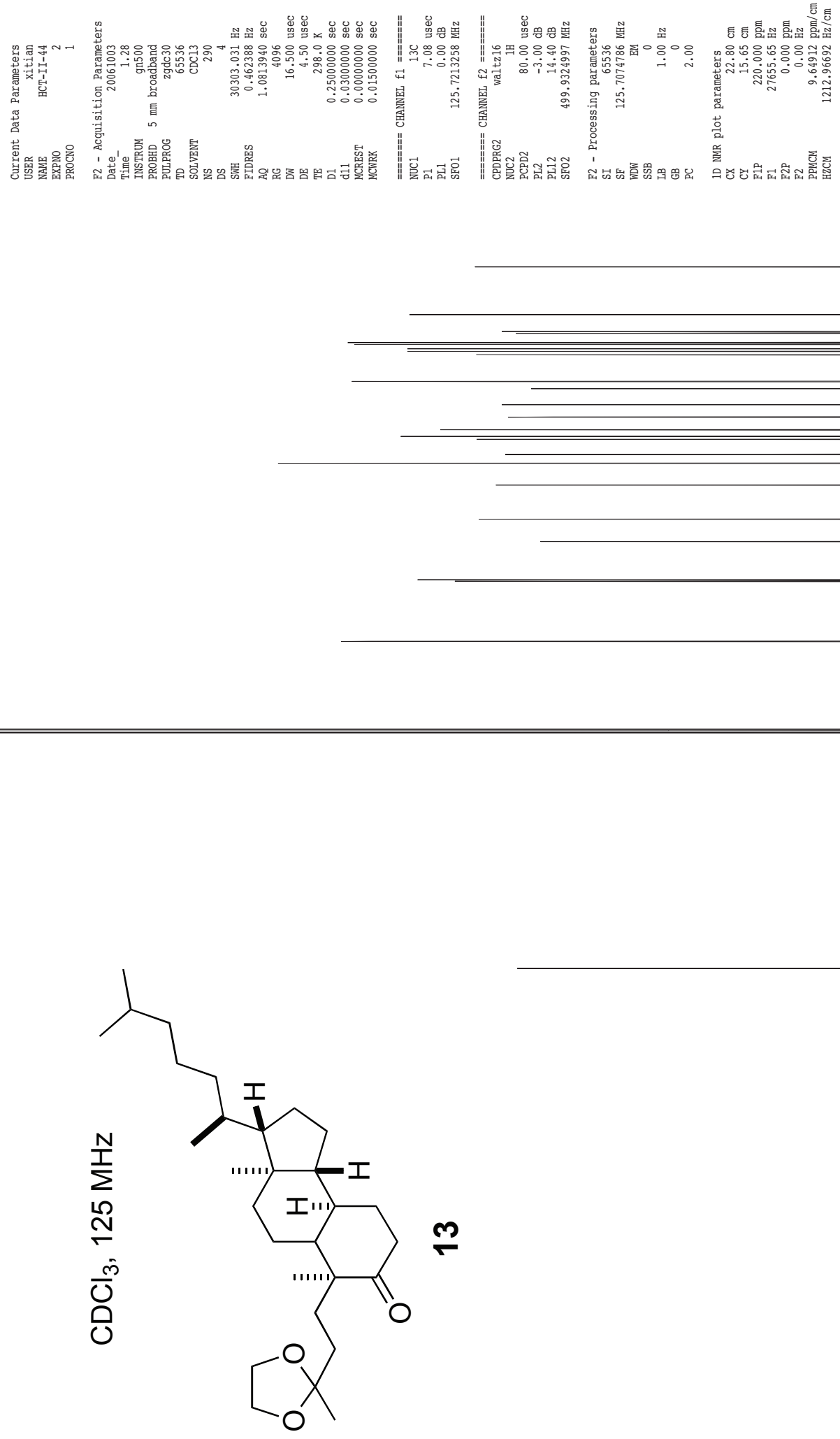


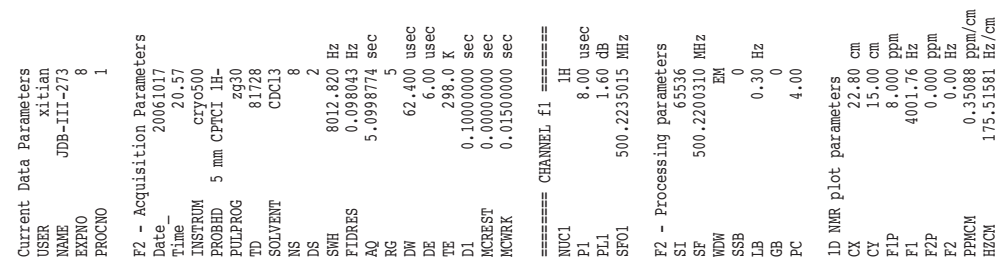



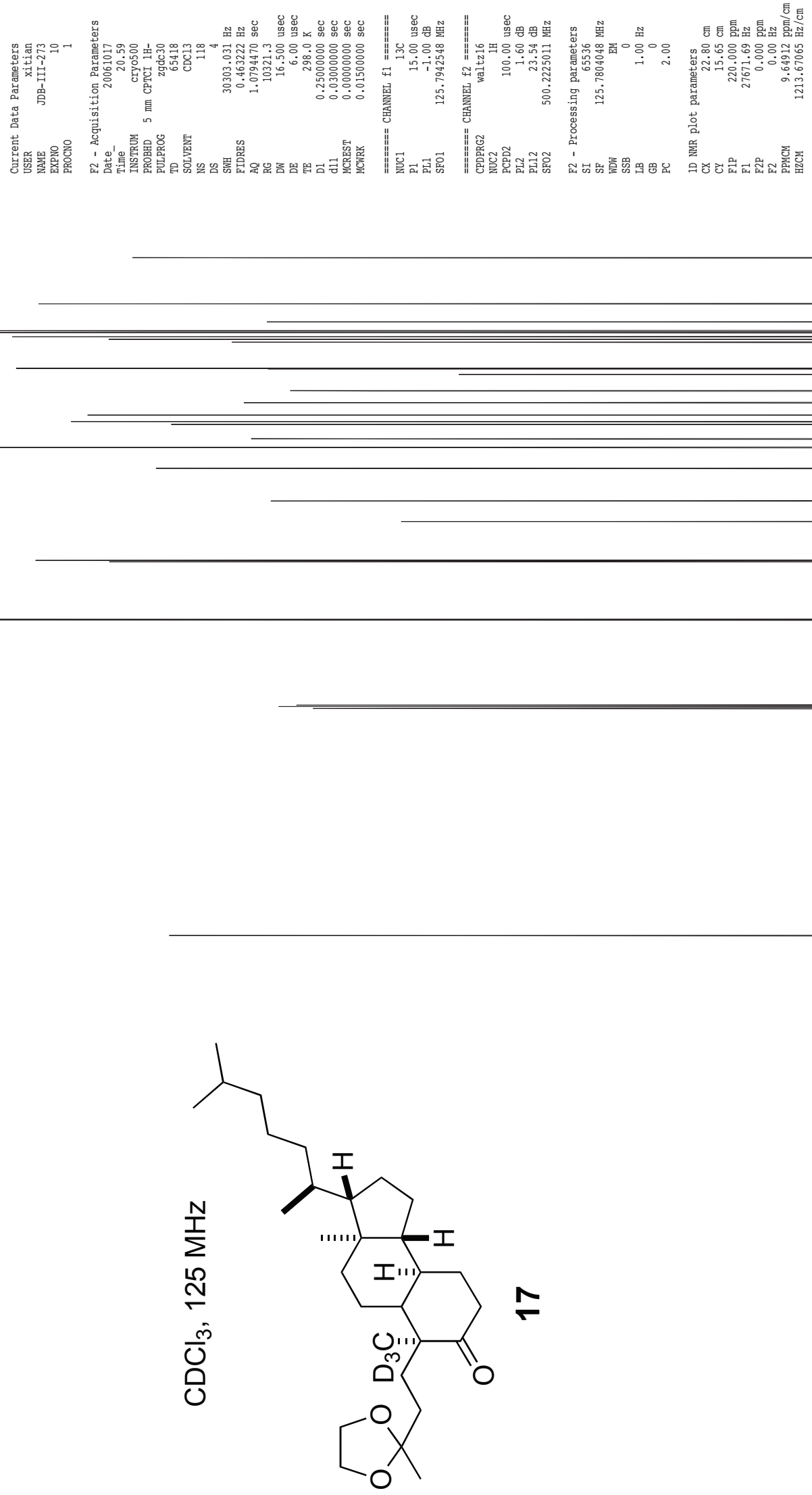
Belani and Rychnovsky

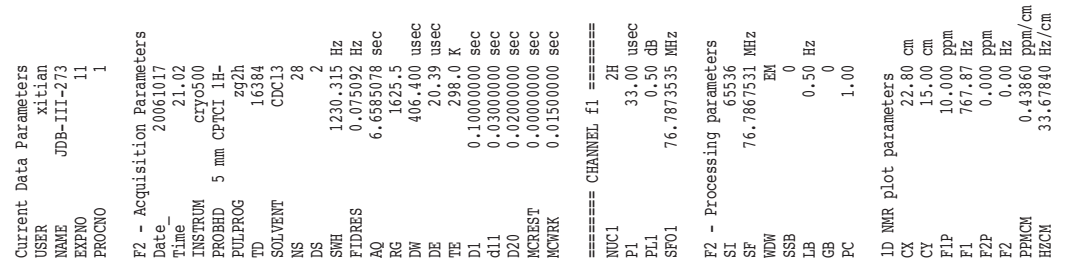

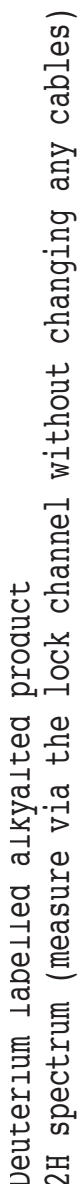

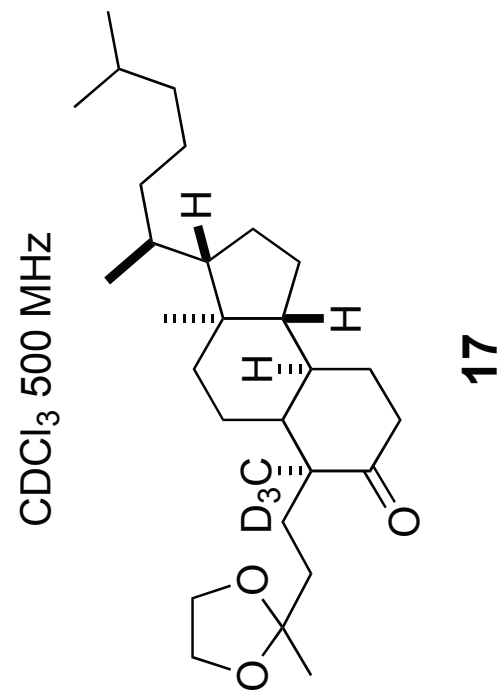



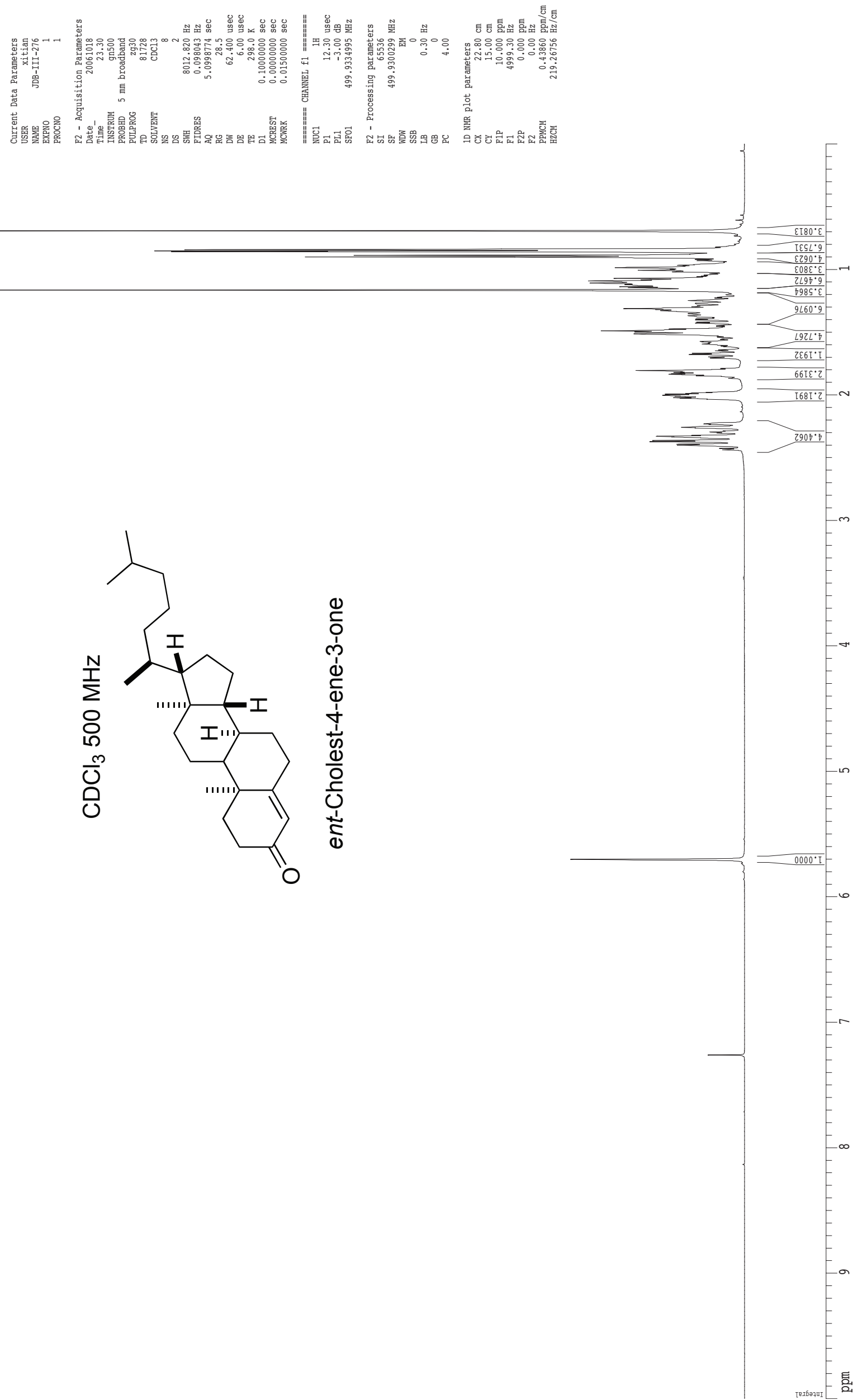

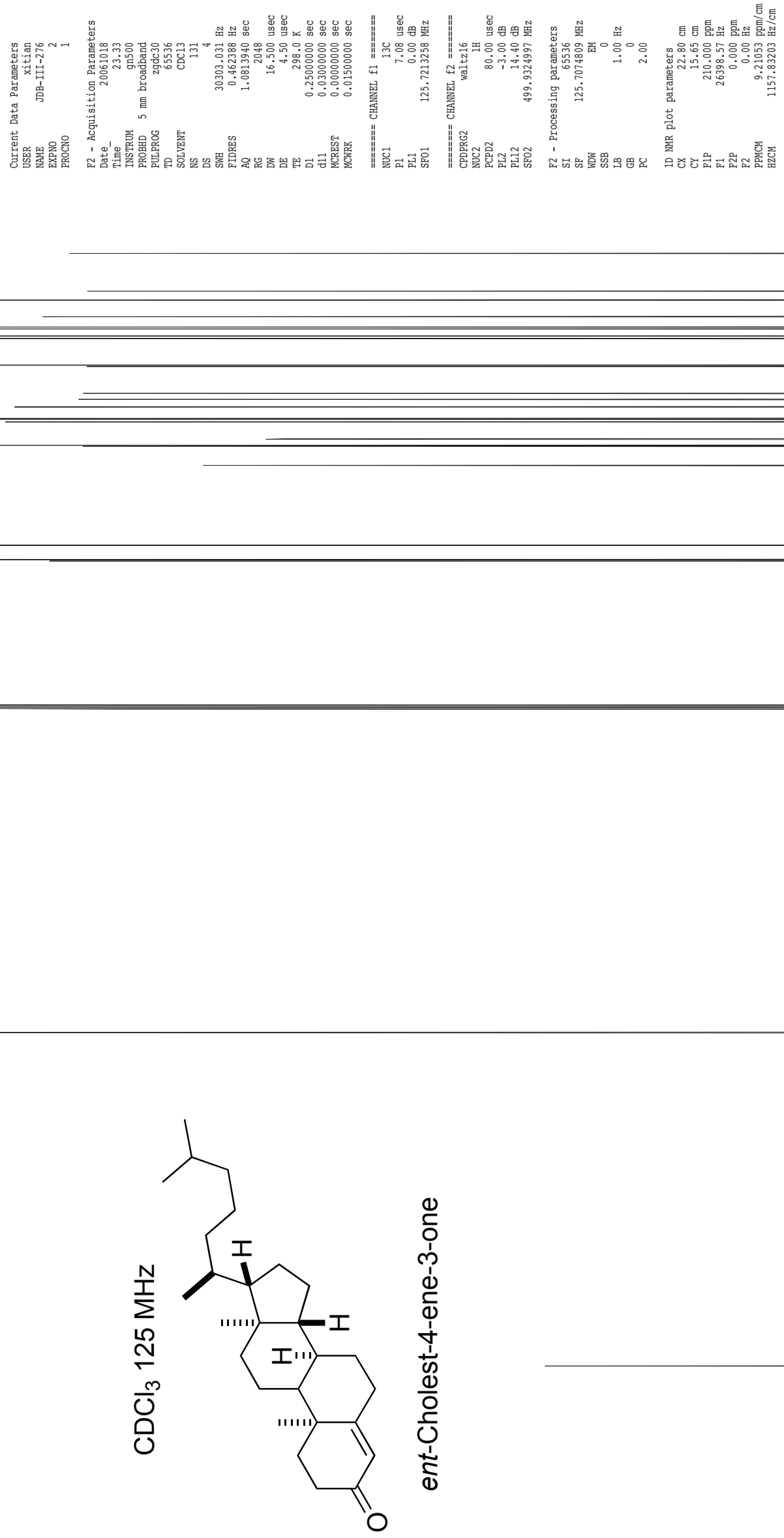

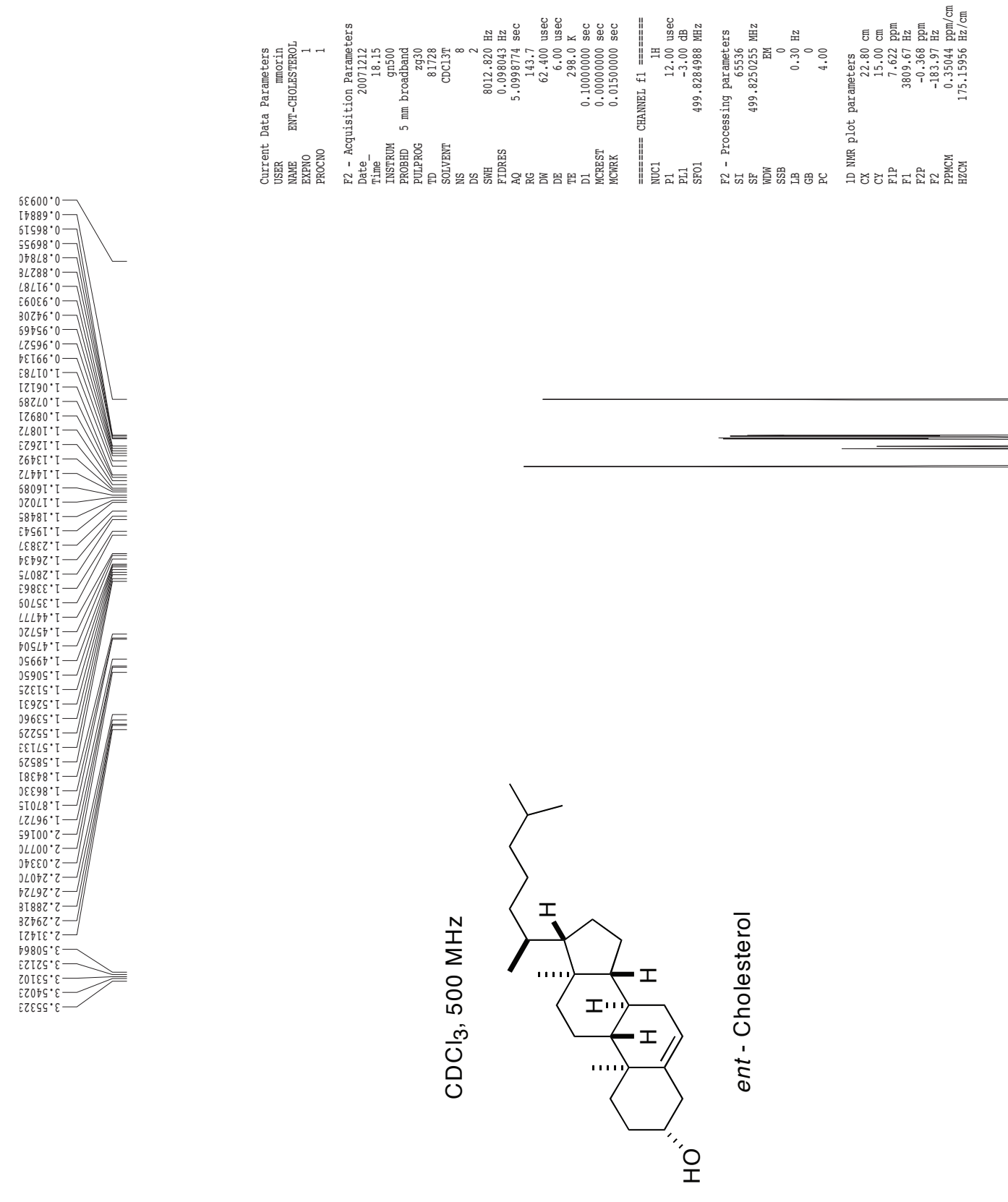

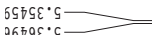

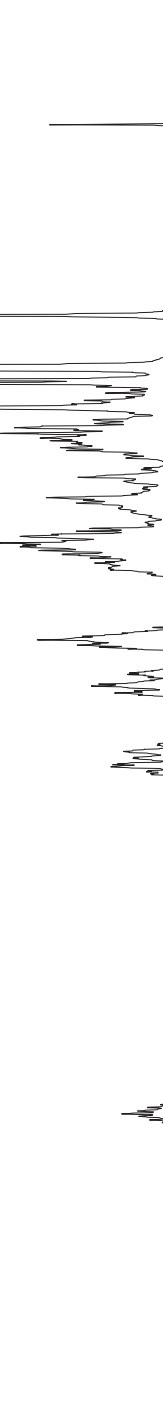

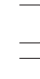
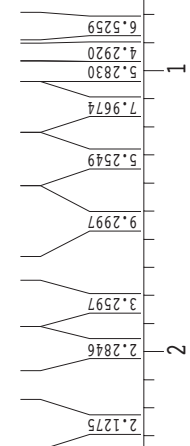

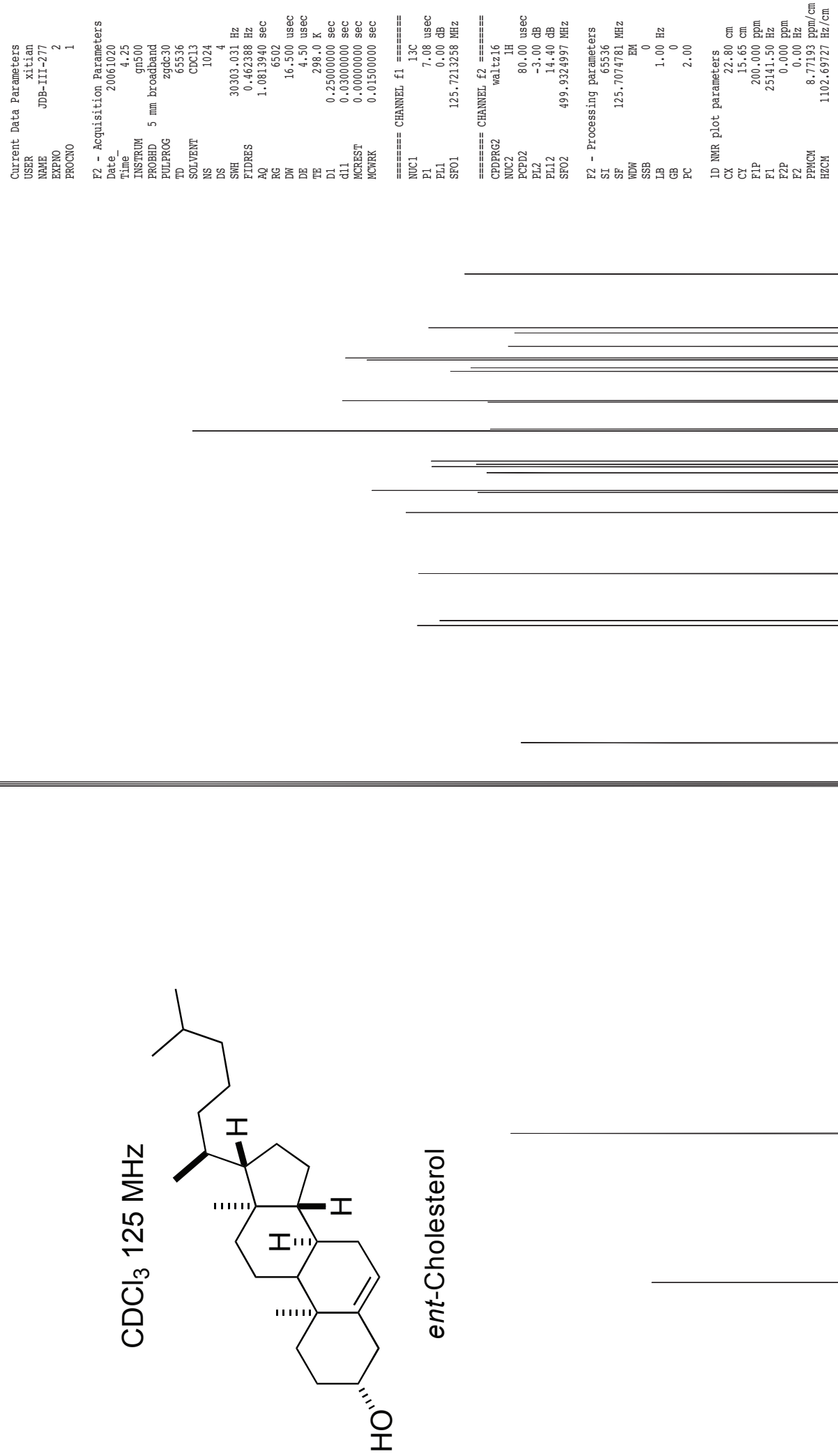

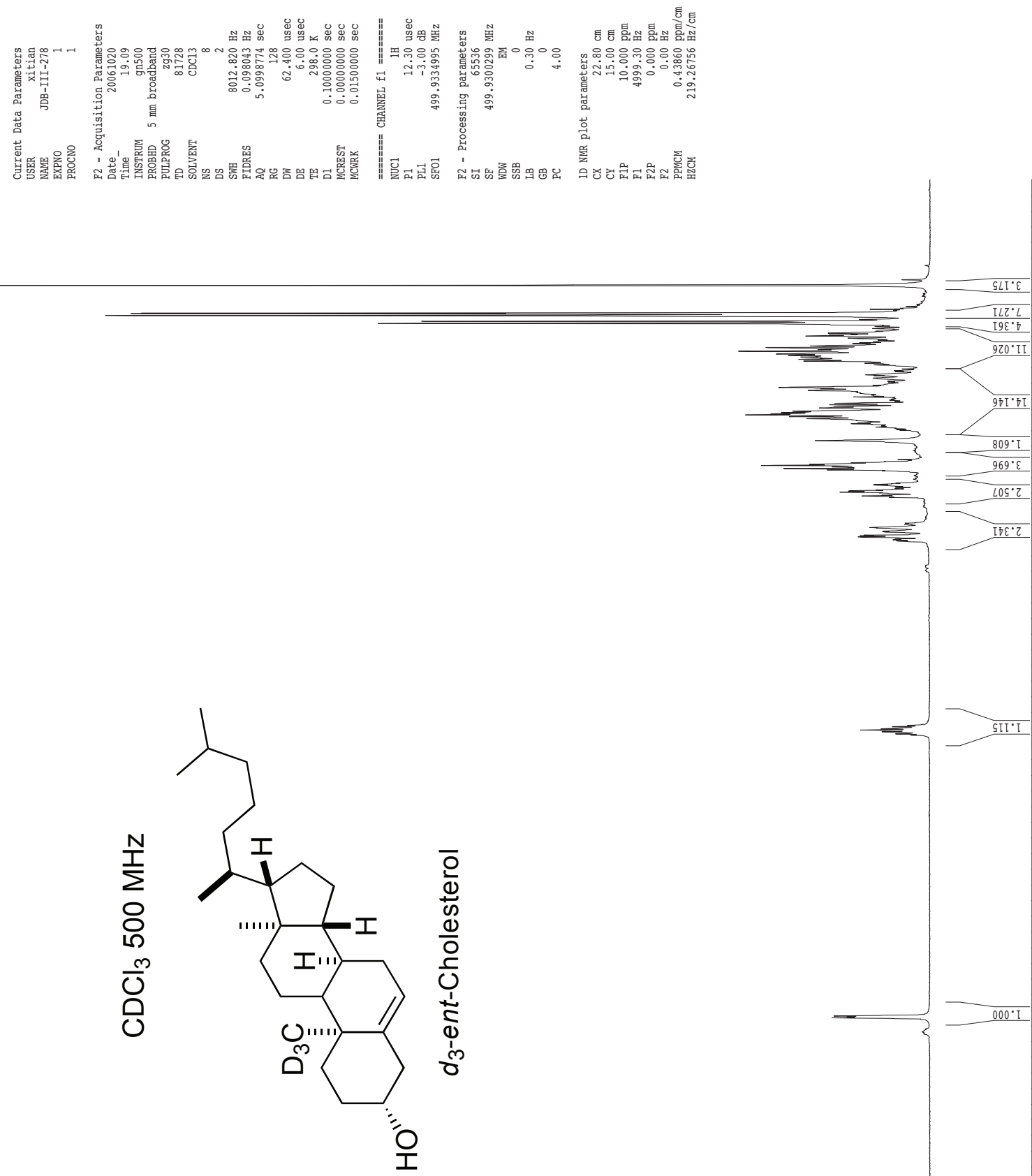

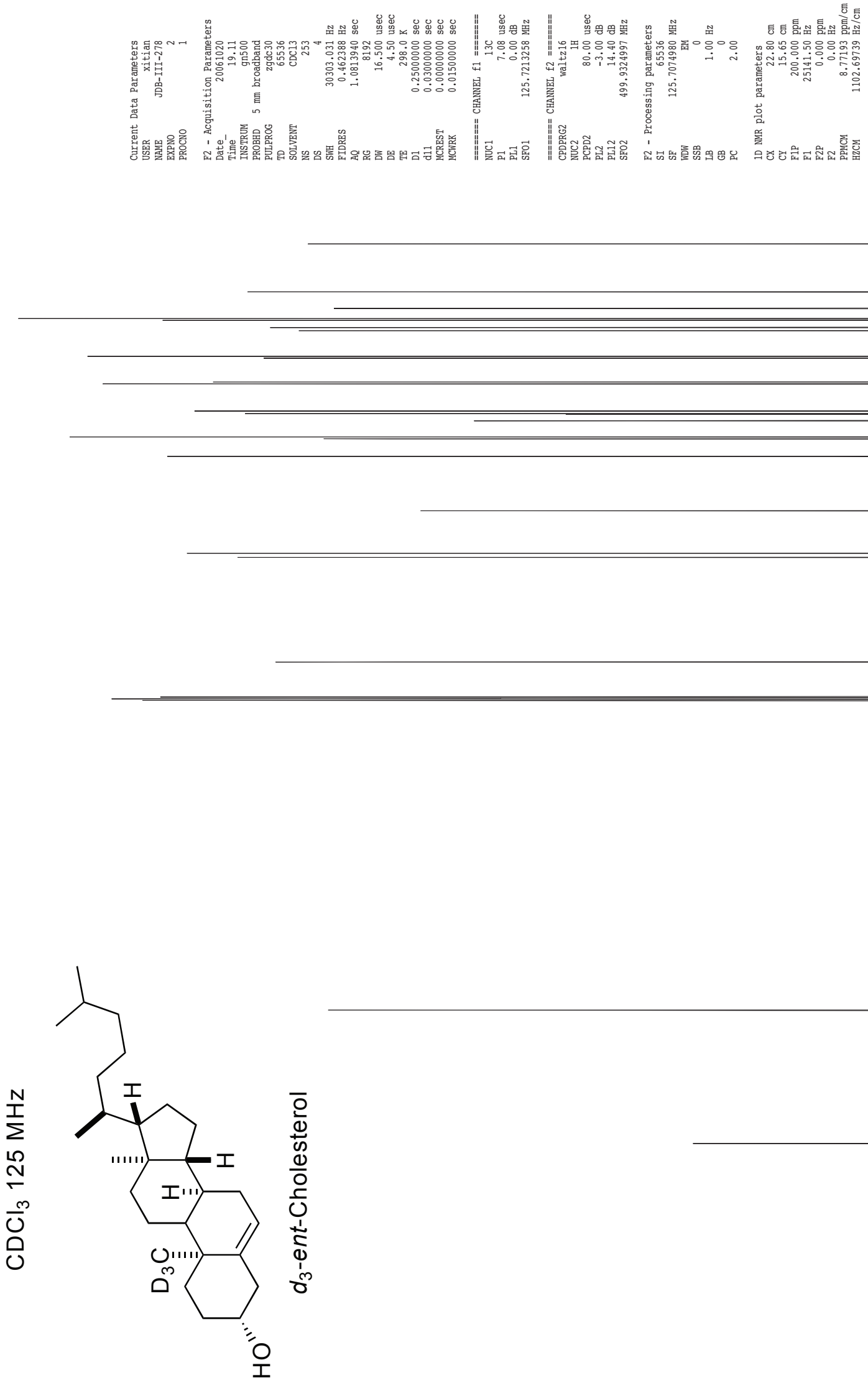